\title{
NITS, GRITS, AND SOFT INFORMATION IN SEC FILINGS
}

\section{CARL W. Schnemer $\dagger$}

The corporate image created by a prospectus, proxy statement, or other Securities and Exchange Commission (SEC) filing may be likened to a shadow-it tells something about the subject's gross outline but in a flat, lifeless, and sometimes distorted form. Many commentators, including SEC Chairman William J. Casey, ${ }^{1}$ have suggested that SEC disclosure filings should be more lifelike representations, devoting greater attention to economic realities and the nitty-gritty of the business, and including certain types of forward-looking information, rather than boilerplate phrases and standard disclaimers which could fit almost any filing.

Historically, certain types of information, highly relevant to investment decisions-referred to herein as "soft" information-have been largely excluded from SEC filings, primarily because of the Commission's policy. Recently, however, the SEC, analysts and other market professionals, the courts, and investors have shown interest in the expanded use of such information in these documents. Consequently its greater use seems to be inevitable.

This Article will consider several categories of soft information traditionally excluded from filings and will examine some of the policy implications of this practice. Since its basic theme is to suggest a shift in attitude to allow, and possibly even require, more soft information in SEC filings, the policies that should control the use of such information will also be explored.

\section{Identification OF SOFT INFORMation}

The content of SEC filings has traditionally been confined to what may be called "hard" information, meaning statements concerning objectively verifiable historical events or situations-commonly

$\dagger$ A.B. 1953, Cornell University; LL.B. 1956, University of Pennsylvania, Member, Pennsylvania Bar.

An abbreviated version of this Article was presented as an address to the 1972 Annual Meeting of the American Bar Association in San Francisco on August 15, 1972. A transcript will appear in the January, 1973, issue of Business Lawyer.

1 See, e.g., Addresses by SEC Chairman Casey: New York Financial Writers Association, June 7, 1971, in 105 BNA SEC. REG. \& L. REP. F-1 (June 9, 1971); American Bankers Association, Mar. 17, 1972, reported in 144 BNA SEC. REG. \& L. REP. A-7 (Mar. 22, 1972); Conference on Financial Reporting, May 19, 1972, reported in 153 BNA SEc. Reg. \& L. REP. A-5 (May 24, 1972). 
called "facts" in SEC parlance-as distinguished from opinions, predictions, or subjective evaluations. Although a comprehensive definition of soft information is not readily apparent, several non-exclusive and non-exhaustive categories can be identified: (1) forward-looking statements concerning the future, such as projections, forecasts, predictions, and statements concerning plans and expectations; (2) statements concerning past or present situations when the maker of the statement lacks the data necessary to prove its accuracy-for example, information on a company's historical share of the market, when it does not have access to precise statistics concerning its competitors; (3) information based primarily on subjective evaluationsfor example, representations concerning the competence or integrity of management, the relative efficiency of a manufacturing operation, or the appraised value of assets; (4) statements of motive, purpose, or intention, since it is frequently easier to verify objectively what was done than to determine why it was done-for example, explanation of the reasons for which an auditor has been discharged; ${ }^{3}$ (5) statements involving qualifying words, such as "excellent," "ingenious," "efficient" and "imaginative," for which there are no generally accepted objective standards of measurement in most contexts. ${ }^{4}$

\footnotetext{
2 The SEC has given particular stress to the difference between "fact" and other types of information in setting forth guidelines for public disclosure of an issuer "in registration." See SEC Securities Act Release Nos. 5180 (Aug. 16, 1971), 5009 (Oct. 7, 1969), 3844 (Oct. 8, 1957); SEC, Disctosure to Investors: A ReappraIsal of FederaI ADMTINISTRATIVe PoLICIES UNDER THE '33 AND '34 ACTs 95-96 (1969) [hereinafter cited as WHEAT REPORT].

3 See Schneider, Developments in 1934 Act Reporting, PLI 3D INST. ON SEC. REG. 110-11 (1972). In certain instances, motive must be disclosed. Cochran v. Channing Corp., 211 F. Supp. 239 (S.D.N.Y. 1962) (anti-fraud rules could be violated by failure to disclose motive for cut in company's dividend rate). But see Lester v. Preco Indus., Inc., 282 F. Supp. 459 (S.D.N.Y. 1965) (allegation that at time of registration officers intended to mismanage corporate funds not sufficient to bring action under anti-fraud rules).

For an example of an attempt to examine motive, see Wall St. J., Nov. 24, 1972, at 4, col. 3: "Asked to explain the resignation [of Lybrand, Ross Bros. \& Montgomery as auditors for International Controls Corp.], an officer replied 'There isn't any one specific reason. In general, it related to our feeling that the auditor-client relationship we desire to maintain can't be so any longer.' Pressed for specifics, [he] declined to list them ...."

Compensating balance arrangements also fall within this category of soft information. "Lack of disclosure [of compensating balance arrangements] has been justified on the grounds that such arrangements were generally unwritten, informal and not subject to precise quantification. None of these reasons are sufficient to support a policy of nondisclosure of a phenomenon which is recognized to be real and significant." Draft guidelines circulated by the SEC, discussed at 180 BNA SEC. REG. \& L. REP. A-10 (Dec. 6, 1972), and reprinted in id. J-1.

4 In preparing a prospectus for a manufacturer of office copying machines, management blithely described the copies produced as "permanent" in discussing the product with the underwriters. This was in an era when many such devices made copies which faded on exposure to sunlight. But what does the word "permanent" mean in relation to a piece of paper, when even Dead Sea scrolls turn brittle around the edges after a few thousand years? Although the businessmen seemed to know what a "permanent" copy was, the lawyers were not certain. The prospectus adopted the circumlocution that the copies would resist deterioration and fading as well as any normal printed matter,
} 
"Hard" and "soft" must be recognized as highly relative concepts suggesting no sharp dividing line. Many apparently hard statements have soft cores and vice versa. Audited historical financial statements are normally considered to be a classic type of hard information. Accounting is not an exact science, however, and many subjective evaluations and other types of soft information must be considered in order to prepare audited financials. ${ }^{5}$ On the other hand, many types of soft information contain an element of "fact." Thus, statements about a man's excellent reputation for integrity and creativity are normally considered to be too soft for inclusion in a prospectus, although existence of a reputation has been considered a "fact" which can be proven in court under traditional rules of evidence. ${ }^{6}$ Similarly, the existence of a plan for the future may be treated for various purposes as a "fact," even though the plan may be very indefinite and subject to many contingencies which often cannot be controlled.

The dividing line between hard and soft information is sometimes bridged by casting statements in terms of beliefs, opinions, or expectations. ${ }^{7}$ Thus, the statement that a company believes itself to be the

whatever that may mean. See Prospectus, Magnefax Corp., SEC Reg. File No. 2-17,943 (May 31, 1961).

5 Soft information in financials relates to such matters as: the establishment of reserves for bad debts, litigation, and tax audits; judgments concerning the degree of profitability and extent of completion of open contracts when using percentage of completion accounting; judgments concerning useful lives of assets (based on factors of wear and also obsolescence) in calculating depreciation; and valuing intangible assets, such as patents or good will of an acquired business. Litton Industries has been questioned for preparing earming statements improperly based upon estimates of a recovery on a $\$ 450$ million claim against the government. See 162 BNA SEc. REG. \& L. REP. A-10 (July 26, 1972). Chairman Casey has recently commented on this area:

It seems vital to me that [accountants] correct the impression that accounting is something which produces exact measurements-that it is a scale on which a business can be weighed to get an exact and precise answer as to its performance and the degree of its progress in any particular period and its value. It seems to me that there is a need for greater public understanding that the accounting process relies on and produces estimates.

Accountants have encouraged the public to think of accounting as an exact science by producing a single number result and limiting accountants' responsibility to a single, segregated section of reports to shareholders, when the essence of the accrual system of accounting is estimation and prediction of future events.

Address by SEC Chairman Casey, American Institute of Certified Public Accountants, Oct. 2, 1972, at 6-7 (emphasis added).

${ }^{6}$ C. McCormarck, Evinence $\$ 44$ (2d ed. W. Cleary 1972). Traditional rules of evidence sometimes distinguished between reputation and character. A man's character is said to be too subjective or elusive an attribute to be a proper subject of evidence, although his reputation is an objective, provable fact.

Reputation, of course, differs somewhat from an opinion held by a particular individual. Id. Thus, a particular individual may hold another person in low regard, although the holder of the opinion may recognize that the subject of the opinion has an excellent reputation.

7 Chairman Casey made a similar point in a recent speech regarding the Commission's reconsideration of its policy on forecasts:

Then, there is the question of whether we can really justify the prohibition of forecasts which are carefully prepared, relied on for budgeting and planning purposes, based on comprehensive data and reasonable assumptions and well articulated and regularly supplemented to reflect supervening developments and 
largest producer of a product purports to be a statement of a "fact"that is, the fact about the belief held-even though the subject of the belief may be soft information, if the company does not have precise information about its competitors.

The Commission has been particularly ingenious in turning soft representations into hard ones (one might call them pseudo-hard) by using the "implied representation" technique. This approach is employed extensively by the SEC in broker-dealer administrative proceedings, typically when a salesman has made a very optimistic forecast expressed in terms of his opinion or belief. The Commission holds that every expression of opinion contains an implied representation of "fact" -namely, the fact that the opinion has an adequate basis. If the Commission discerns no adequate basis for the opinion, it finds a misrepresentation in this implied factual representation. ${ }^{8}$

The dividing line may be especially blurred when dealing with the future, depending on whether the statement is an affirmative representation about what will occur or a statement about a present plan or expectation for the future. The relative hardness of a statement should turn less on its form (for example, a statement concerning what will happen as opposed to a statement of present expectation) and more on the underlying substance. If a company has a firm agreement to buy a property, with closing scheduled ten days after the effective date of its prospectus, and all closing preconditions have been satisfied, a statement that the company "will" (or presently proposes to) purchase the property may be considered reasonably hard, and, therefore, acceptable for prospectus inclusion under current practice. But a statement that the company will (or even the softer statement that it presently expects or proposes to) open one hundred additional branches over the next five years, when no further locations have been selected, would be too soft for inclusion in a prospectus under prevailing standards.

\section{Prevalimg Practices of Exclusions}

There has been something of a "conspiracy of silence" in excluding soft information from SEC filings. The Commission and private parties preparing SEC filings, each for their own reasons, have generally (with

revisions in estimates. If we do prohibit forecasts which a company makes and circulates, are we subjecting the company to statutory liability for failure to disclose a material fact? The forecast is an estimate but its existence and the articulated judgment it represents is a fact.

Address by SEC Chairman Casey, Financial Executives Institute, Oct. 18, 1972, at 16-17 (emphasis added).

8 Cohen \& Rabin, Broker-Dealer Selling Practice Standards, 29 Law \& Contente. Pros. 691, 704-05 (1964). The Commission has gone so far as to establish conclusively that certain types of opinions may never be adequately based in fact, such as opinions that there will be a very sharp rise in the market price of a speculative security. 
some exceptions) excluded soft information from such filings. Although the prevailing attitude on soft information has emerged primarily in contexts concerning registration statements filed under the 1933 Act, ${ }^{9}$ the same approach is normally applied (with some exceptions) on a fairly uniform basis to other types of filings-proxy statements and periodic reports for example.

\section{A. The Traditional SEC Position}

The Commission has been motivated by a desire to protect investors against questionable selling literature, as well as to aid in the enforcement of statutory liabilities. ${ }^{10}$ SEC filings, especially 1933 Act prospectuses, traditionally have been considered to be among the most accurate and reliable (although not necessarily the most useful) sources of information available to investors. The Commission tries to confine these documents to hard information to assure a continued high degree of reliability. Moreover, since it is generally more difficult to prove an inaccuracy in soft information, the limitation of filings to hard information makes it easier to establish accountability for inadequate disclosures.

Furthermore, according to the traditional SEC view, the inclusion of soft information in filings would clothe such information with an unduly high aura of credibility. Investors assume, with a great deal of justification, that information appearing in SEC filings has been prepared with considerable care, tending to assure its accuracy. ${ }^{11}$ Therefore, under the SEC's approach, if soft information appeared in a prospectus, the public would incorrectly assume an unwarranted degree of reliability - that a prediction or projection would almost certainly be fulfilled, or that any statement made is subject to verification by objective evidence.

The bootstrap element in this logic is apparent. If the public assumes that filed information is completely verifiable by objective data, Act].

${ }^{\theta}$ Securities Act of 1933, 15 U.S.C. $\S \S 77$ a et seq. (1970) [hereinafter cited as 1933

10 For two excellent and rather critical expositions of the traditional SEC position, see Kripke, The SEC, the Accountants, Some Myths and Some Realities, 45 N.Y.U.L. Rev. 1151 (1970) [hereinafter cited as Myths]; Mann, Prospectuses: Unreadable or Just Unread?-A Proposal to Reexamine Policies Against Permitting Projections, 40 Geo. WASH. L. REv. 222 (1971) [hereinafter cited as Prospectuses]. A more sympathetic analysis of the SEC position appears in Heller, Disclosure Requirements Under Federal Securities Regulations, 16 BUS. LAw. 300 (1961). For a judicial exposition of the traditional SEC view, see Union Pac. R.R. v. Chicago \& N.W. Ry., 226 F. Supp. 400, 408-09 (N.D. III. 1964).

11 Investors may also assume, with some though by no means total justification, that the SEC itself has verified the statements in a prospectus, notwithstanding the boldface warning on the cover to the contrary. The Staff certainly does make comments or requests for supplemental information designed to verify the accuracy and adequacy of some disclosures, especially those which have elements of softness. 
it does so precisely because filings have been confined in the past to hard information. This cause and effect cycle could be broken easily, however, if a new policy were adopted to permit greater use of soft information in filings. Indeed, the Commission's view does not deny either the relevance of soft information in making investment decisions, or the fact that soft information is used extensively (and quite appropriately) by investors. Rather, the traditional Staff attitude may be summarized to the effect that soft information is all right in its place, but an SEC filing is not its place.

The SEC's hostility to soft information is particularly evident in its comment letter practice. With insights sometimes suggestive of paranoia, the Staff has shown particular zeal for detecting, and requesting the deletion of, implied predictions in seemingly inoffensive language. Also Staff requests for supplemental information (for its own use but not for inclusion in filings), apply with disproportionate frequency, and occasionally with chilling effect, to statements suspected of being soft, such as representations about a company's competitive position, or about the management's beliefs in that regard. ${ }^{12}$

\section{B. Acquiescence by Private Parties}

Issuers, underwriters, and their counsel generally have acquiesced as a matter of self-protection in the traditional exclusionary policy of the SEC regarding soft information. They are not anxious to assume needless exposure to potential liability by making soft representations which may be difficult to substantiate, especially if a reasonably based soft statement (such as a prediction or subjective evaluation) made in good faith proves to be incorrect.

Since securities are sold primarily through oral sales efforts, with supplemental information often being supplied to dealers through underwriters' memoranda which are not filed with the SEC, ${ }^{13}$ there has been relatively little pressure by issuers and underwriters to allow (or re-

12 In one situation in the author's experience, the initial filing set forth management's broadly stated beliefs about the company's industry position. This belief was based primarily on the accumulated feel for the industry acquired by the executives over many years of personal contracts. Management's more specific beliefs, expressed privately to the underwriters in preparing the registration statement, could have been erroneous by a wide margin, and still the much more general statement in the prospectus would have been completely accurate. Despite the absence of objective data, counsel and underwriters were completely satisfied with the statement made in the initial filing. On review, however, the Staff raised so many questions about the basis for management's belief, that the statement was finally modified rather than risk further delay by prolonged discussions. Cf. Chris-Craft Indus., Inc. v. Bangor Punta Corp., 426 F.2d 569 (2d Cir. 1970) (disclosure of "fact" of anticipated price per share considered improper), discussed in SEC, Consequences of Corporate Acquisitions 172-77 (C. Schneider, J. Bauman \& H. Wander eds. 1971).

${ }_{13}$ Such documents may be supplied supplementally to the SEC (SEC Securities Act Release No. 4936, II 42 (Dec. 9, 1968)), but they are not "filed" or subject to the liabilities which attach to deficient filings as such. 
quire) more soft information in prospectuses. A prospectus is a somewhat schizophrenic document, which might serve either a selling or liability-prevention function. Faced with the enormous potential liabilities for a deficient filing, most private parties have opted to stress the preventive function, treating the prospectus as an insurance policy. ${ }^{14}$ They can take comfort in the knowledge that the prospectus contains only statements that are demonstrably provable by objective evidence already at hand.

Additionally, preparation of a filing in accordance with the traditional formula can reduce the delay and trauma inherent in the processing procedure. A pragmatic adjustment to these realities by those who prepare filings has ingrained habits very deeply, and consequently the traditional approach has become a generally accepted pattern. One actively engaged in the securities business can easily forget how stylized and stilted this genre of literature appears to the uninitiated.

\section{Exceptions to the Practice of Exclusion}

Exceptions exist to the general policy of excluding soft information. One may detect a wide variety of relatively soft statements in many filings. For example, the application of proceeds section of prospectuses and certain data in Form S-11 (the form for various types of real estate offerings) ${ }^{15}$ expressly require forward-looking information. The introductory statement in a prospectus, which describes so-called risk factors and speculative aspects, tends to develop some soft areas. ${ }^{16}$ Furthermore, there has apparently been a slight shift in the Commission's attitude recently, resulting in more toleration of soft information in filings when it is particularly material and useful to investors. ${ }^{17}$ For instance,

\section{See text accompanying notes 30-31 infra.}

${ }^{15}$ See SEC Form S-11, Item 6(b), calling for future estimates of cash flow and taxable income in certain cases.

16 SEC Securities Act Release No. 4936, Guide No. 6 (Dec. 9, 1968), as amended, SEC Securities Act Release No. 5278, Guide No. 6 (July 26, 1972).

17 The Commission's recent suggestions regarding prospectuses of broker-dealers which offer their own securities publicly may well reflect this trend. See SEC Securities Act Release No. 5222 (Jan. 3, 1972). These suggestions expressly call for various types of soft information. The guidelines as a whole convey the impression that more soft information than has been typical would not only be tolerated, but would be required in prospectuses of broker-dealers.

For example, the Commission suggests discussion concerning the competitive impact on the issuer-which might well be favorable- of developments such as access of financial institutions and broker-dealers to various market places, the impact of NASDAQ and other automated quotation systems, revision of commission rate structures, trends toward public ownership, antitrust implications of present industry practices, and pending proposals for industry change. Id. II 5 . These topics represent highly sensitive and unclear areas, in a state of flux with numerous unknowns. The Commission historically has neither expected nor required discussions of comparable imponderables which face issuers in other industries. The Commission's intimate familiarity with the brokerage business no doubt gives it confidence that it can exercise some independent judgment in processing broker-dealer filings, a factor which probably increases its willingness to deal with soft information concerning this particular industry. 
the Staff is reconsidering its traditional prohibition of financial projections in filings. ${ }^{18}$ Such a shift in attitude is clearly consistent with Chairman Casey's call for more economic reality. ${ }^{10}$

As a matter of practice, the Commission has been more tolerant of soft information in filings concerned with acquisitions (mergers, exchange offers, and so forth), tender offers, and proxy contests. ${ }^{20}$ In these situations an investor most clearly needs "fair," as contrasted with "conservative," disclosure. When an investment decision involves a choice between two securities (or two managements), the alternate choice may seem to be relatively better than it really is, if an overly conservative presentation makes one security (or management) appear worse than it in fact is. Furthermore, in an adversary situation, such as a proxy contest or disputed tender, each contestant can raise appropriate challenges to the soft information offered by the other, thus tending to assure that investors will not be misled.

Furthermore, the SEC has adopted a double standard, depending on whether soft information is favorable or adverse. It has considered

18 See SEC Exchange Act Release No. 9844 (Nov. 1, 1972). A recent proposal for more disciosures regarding substantial write-offs and charges against income would also call for a great deal of predictive information. SEC Securities Act Release No. 5313 (Oct. 2, 1972).

10 Chairman Casey drew particular attention to the economic realities relating to compensating balance arrangements for bank loans. Address by SEC Chairman Casey, American Bankers Association, Mar. 17, 1972, reported in 144 BNA SEC. REG. \& L. REP. A-7 (Mar. 22, 1972). He stated that disclosure could not be avoided merely because there was no written contractual commitment. In many cases, disclosure of non-contractual compensating balance arrangements would be relatively soft, since the arrangements may be vague. Although Chairman Casey indicated that the Commission has "not yet required this form of disclosure for companies under our 1933 Act powers," Staff comment letters recently have been requesting disclosure of compensating balance arrangements. Id.

Chairman Casey has urged public companies to give more evaluation and forwardlooking information in annual reports to shareholders. Address by SEC Chairman Casey, American Society of Corporate Securities Annual Meeting, June 6, 1972, reported in 156 BNA Sec. REg. \& L. ReP. A-19 (June 14, 1972). The Commission has been pressing to have disclosures in Form 10-K reports to the SEC and disclosures in annual reports to shareholders become more equivalent. Id. SEC Exchange Act Release No. 9672 (July $26,1972)$. The result inevitably may be Form $10-\mathrm{K}$ reports which come closer to the style of disclosure used in annual shareholders reports, including soft information.

20 Indeed, in at least one situation, traditional roles were reversed and the Commission insisted on the inclusion of long term financial projections in an acquisition proxy statement. The issuer vigorously resisted on the grounds that the particular projections, under the assumptions prescribed by the Commission, did not represent a realistic forecast of the future, and that the public might give undue predictive significance to the projections, notwithstanding disclaimers, simply because they appeared in an SEC filing. The projections requested by the Staff made no allowance for the economic reality motivating the transaction-the expectation that significant economies would result from the combination of two similar businesses.

A significant amount of the litigation challenging the adequacy of disclosure under the anti-fraud rules relates to alleged deficiencies in relatively soft information, typically future plans, in connection with acquisitions. See, e.g., Kohn v. American Metal Climax, Inc., 458 F.2d 255 (3d Cir.), cert. denied, 93 S. Ct. 120 (1972); Susquehanna Corp. v. Pan American Sulphur Co., 423 F.2d 1075 (5th Cir. 1970) ; Feit v. Leasco Data Processing Equip. Corp., 332 F. Supp. 544 (E.D.N.Y. 1971); Gerstle v. Gamble-Skogmo, Inc., 298 F. Supp. 66 (E.D.N.Y. 1969); Mills v. Sarjem Corp., 133 F. Supp. 753 (D.N.J. 1955); Speed v. Transamerica Corp., 99 F. Supp. 808 (D. Del. 1951), aff'd, 235 F.2d 369, 373 (3d Cir. 1956). 
disclosure of soft information to be mandatory when the information creates fairly specific and highly negative inferences, although disclosures on the same subjects are normally prohibited if the information is favorable. It has required negative disclosures, for example, on such topics as plant efficiency, ${ }^{21}$ management integrity, ${ }^{22}$ labor relations, ${ }^{23}$ pending antitrust negotiations with the Justice Department, ${ }^{24}$ anticipated changes in a company's competitive position, ${ }^{25}$ or trends reflected in recent interim earnings ${ }_{2}{ }^{26}$ topics on which favorable disclosures would probably be prohibited.

As another indication of changed attitude, the Commission recently proposed various steps to control abuses of hot issues. ${ }^{27}$ Several of the proposals relate to expanded disclosure obligations and, to a significant extent, they deal with soft information. Thus, there is a proposal to add new disclosure obligations for issuers filing a first 1933 Act registration statement who have not conducted bona fide operations for a period of at least three years prior to the filing. Their prospectuses would be required to: "Describe, if available, the registrant's plan of operation" for the immediate future, the disclosure to "include such matters as: (a) If available, a budget of anticipated cash expenditures and resources which should present on a quarterly basis the principal categories of expenses expected to be incurred . . .."28 These proposals reflect Chairman

21 Clinton Engines Corp., SEC Securities Act Release No. 4724 (Sept. 28, 1964).

22 Franchard Corp., SEC Securities Act Release No. 4710 (July 31, 1964).

23 Levitz Furniture Corp., SEC Securities Act Release No. 5295 (Sept. 6, 1972), holding that a prospectus should have disclosed "to the extent possible ... the effects of [the union's] organizing campaign and the proposed labor contract terms on registrant's business operations, employee relations and income." Id. at 3. But see Prettner v. Aston, 339 F. Supp. 273, 290-91 (D. Del. 1972) (no need to speculate about adverse impact of merger on labor relations, where "there had not been a work stoppage or strike in similar circumstances in the preceding ten years").

24 The SEC charged ITT with violating the anti-fraud rules for failing to disclose material information in a prospectus supplement, regarding a change in the settlement posture, the substance of settlement negotiations and subsequent material developments in the negotiations between ITT and the Justice Department relative to ITT's alleged antitrust violations. SEC v. International Tel. \& Tel. Corp. CCH FED. SEC. L. REP. 【 93,535 (S.D.N.Y. June 20, 1972) (consent injunction on complaint described in 157 BNA SEc. Reg. \& L. REP. A-6 (June 21, 1972)). Describing accurately the posture of a negotiation which is not yet completed is extremely difficult due to the highly subjective nature of the evaluation to be made, the fact that each party may not be stating its most conciliatory position to the other, and the possibility that a party's position might be jeopardized if it had to make public disclosures which become available to the other party about its view of the negotiations.

25 See SEC v. Granco Products, Inc., 236 F. Supp. 968, 971 (S.D.N.Y. 1964); Universal Camera Corp., 19 S.E.C. 648, 655-56 (1945) (anticipated problems in transition from wartime to peacetime market).

26 Doman Helicopters, Inc., 41 S.E.C. 431 (1963).

27 SEC Securities Act Release Nos. 5274-79 (July 26, 1972).

28 SEC Securities Act Release No. 5276, at 7-8 (July 26, 1972) (proposing amendments for Form S-1). Corresponding changes were proposed in Form S-2 and Exchange Act Forms 10 and 10-K. 
Casey's view that disclosures should focus on economic reality. ${ }^{29}$ The Chairman has specifically rejected the insurance policy analogy, ${ }^{30}$ often used by securities lawyers, ${ }^{31}$ as being an appropriate point of orientation for a prospectus.

Whatever objections one may have to the specific proposals, they should be welcome insofar as they reflect a breakdown of the Commission's generally rigid attitude banning soft information. However, the hot issue proposals have a very specific orientation. The Commission was quite concerned with "new ventures which seem to have little or no actual economic viability."32 Thus, despite some minor indication to the contrary, ${ }^{33}$ the general theme underlying the several interrelated proposals seems to be an effort to force disclosure of more adverse or negative information.

The hot issue proposals grew out of a study of the specific problems generated by hot issues, not out of an overall reevaluation of disclosure policy. The proposals thus did not focus on the fact that almost all issuers, including the strongest and most successful companies, have available soft information that would be useful to potential investors. Rather, the focus of attention was on high risk companies which were going public without meaningful disclosure of such risks.

Thus, we have an anomaly. The first Commission proposal for forward-looking financial information in filings, in the form of budgets, would be mandatory and would apply only to those companies which, as a class, would probably find it the hardest to develop reliable predictions-start-up enterprises filing a first registration statement. The Commission did not make any concurrent proposal to permit (or require) forward-looking financial data for well-established companies which presumably would have both the historical data and the management skill for preparing reliable earnings forecasts. ${ }^{34}$

29-See speeches cited in note 1 supra.

30 Address by SEC Chairman Casey, Texas Bar Association, in 160 BNA Sec. Reg. \& I. REP. A-3 (July 12, 1972).

31 E.g., Schneider \& Manko, Going Public: Practice, Procedure and Consequences, 15 VIII. L. REv. 283, 293 (1970).

32 SEC Securities Act Release No. 5275, at 2 (July 26, 1972).

33 A proposed revision in Form S-1, Item 9, Instruction 2, calls for expanded information on "positive and negative factors pertaining to the competitive position of the registrant." SEC Securities Act Release No. 5276, at 6 (July 26, 1972). It remains to be seen how the Staff would administer the provision relating to positive competitive factors, where a start-up enterprise believed that its intended method of operations for the future would give it an advantage over well-established competitors.

34 For some time, the Commission has been actively considering a more general use of financial projections in filings. It has solicited opinions from several industry groups and hearings in this area were scheduled to begin November 20, 1972; see SEC Exchange Act Release No. 9844 (Nov. 1, 1972). 


\section{The Need for Change}

\section{A. Effects of the Traditional Approach}

Most SEC filings have a tone of extreme "conservatism," with a tendency to accentuate all negative, pessimistic, adverse, or "bearish" factors, and much more explanation of the down-side risk than the upside potential. The traditional practice has been oriented toward the potential new investor, and reflects a policy judgment that it is highly important to protect him against buying a security which is worse than he thinks, but relatively less important to protect him against missing a favorable opportunity.

Often the result is not, in fact, "fair," "balanced," or "realistic" disclosure in any meaningful sense, but rather disclosure which is unbalanced and unduly pessimistic. One experienced practitioner describes the typical executive's reaction to his company's prospectus as: "If I believed that was a fair picture of the company, I'd look for another job."35 Thus SEC filings generally have an artificial or unreal quality. They purport to be full disclosure documents but, as a matter of convention, they exclude important types of information investors consider relevant, and stress much information investors consider irrelevant or relatively unimportant. ${ }^{36}$ Although the ban on soft information is most effective in excluding favorable information, it often serves as well to screen negative aspects of a company from the public. ${ }^{\text {37 }}$

\section{B. Criticisms of the Traditional Approach}

A district court recently characterized prospectuses in damning terms-and it is noteworthy that the opinion refers to prospectuses in general and not simply the particular prospectus before the court in the lawsuit:

In at least some instances, what has developed in lieu of the open disclosure envisioned by the Congress is a literary

35 Prospectuses, supra note 10 , at 231 n.43.

36 Disclosure serves useful functions in addition to conveying information relevant to investment decisions. Disclosure is a deterrent against over-reaching as well as an aid to enforcement. To a large extent, the detailed information on compensation, executive stock options, and transactions with management serve principally to deter over-reaching and are of little informational value to investors. The very fact that disclosure is required helps to insure that a transaction will be reasonable and therefore uninteresting to investors who read disclosure filings for investment information. Without suggesting that disclosures of this nature should be eliminated, they could be reduced without diminishing the deterrent effect.

It is interesting to compare SEC filings with investment manuals prepared by commercial services. The manuals are specifically designed to give investors the type of information desired for making investment decisions. It is very rare for these manuals to include any of the prospectus type information relative to compensation, management perquisites, and management transactions.

37 The Commission's proposed hot issue controls are, in large measure, an attempt to remove this screen. 
art form calculated to communicate as little of the essential information as possible while exuding an air of total candor. Masters of this medium utilize turgid prose to enshroud the occasional critical revelation in a morass of dull, and-to all but the sophisticates-useless financial and historical data. In the face of such obfuscatory tactics the common or even the moderately well informed investor is almost as much at the mercy of the issuer as was his pre-SEC parent. He cannot by reading the prospectus discern the merit of the offering. ${ }^{38}$

Professor Homer Kripke, a leading member of the academic community (whose career has included service as a senior Commission official), states:

I have reluctantly come to the conclusion that the Securities Act of 1933 is not operating as it should, that the prospectus has become a routine, meaningless document which does not serve its purpose. ${ }^{39}$

Professor Kripke characterized the prospectus as "perfunctory," "sterile" and "fairly close to worthless." A leading securities lawyer has similarly summarized the situation:

The real problem with the statutory prospectus is not that it is unreadable, but that it is unread. It is unread because it does not contain that information which the investor considers crucial to his investment decision. ${ }^{41}$

The disclosure problem has usually been viewed as paramount. Two thoughtful securities analysts have criticized the SEC's policy of viewing disclosure

as merely a branch of trading regulation ... to insure fairer markets at the expense of serious investors .... [W] hat the SEC thinks is a material fact is not necessarily what those involved in using facts consider either material or fact. Investors 1971).

38 Feit v. Leasco Data Processing Equip. Corp., 332 F. Supp. 544, 565 (E.D.N.Y.

30 Address by Homer Kripke, Annual Meeting of Banking, Corporation and Business Law Section, New York State Bar Association, Jan. 27, 1972, Proceedings at 19. Professor Kripke also offered this interesting metaphor:

We would not think much of a military general staff or intelligence staff which told the field commander that they were not going to give him their estimates as to the enemy's strength and dispositions for fear that they might not be accurate or complete, but would prefer to give him something that they were sure was reliable, like information about the enemy's dispositions in World War Id. 26 .

II. And yet that is essentially comparable to what the Commission is doing.

40 Id. 19-20.

41 Prospectuses, supra note 10 , at 223. 
ought to be able to get more facts which the SEC does not now consider either material or fact. ${ }^{42}$

\section{Chairman Casey reached a similar conclusion:}

Disclosure has been an arcane business. The real problem of securities work is that the caution that has gone into the disclosure process has produced items so carefully hedged that few investors can make use of them. Reams of boiler plate incantations were spawned by years of lawyers looking out for their client companies. These doom-filled documents have become largely ignored in the fourth decade of their existence ....

[A] backward looking prospectus only tells half of the story. Investors do not put up their money solely on the basis of past history. They are always partly sold, and particularly in the new issue area, by verbal assurances about the prospects of the company. Such projections are at least as valuable, if not more so, than the past three year's financial record, particularly if the company is just starting up.3

These harsh criticisms, each of which is related, at least in part, to the exclusion of soft information, should be evaluated in context. It would be an overstatement to suggest that every prospectus is totally useless. Even with a revised approach towards soft information and other standards of disclosure, it may well be that prospectuses for some issuers would remain essentially as they are under current standards. But, in a significant number of instances, reading a prospectus without soft information is like watching a performance of Hamlet with the role of the prince unfilled. In either case, the viewer may get some interesting tidbits of background information, but very little idea of what the real story is all about.

The purpose of the disclosure statutes is frustrated, to the disadvantage of public investors, when available material information is kept out of disclosure filings. In balancing competing policy goals-to inform

12 Whitman \& Shubik, Corporate Realty and Accounting for Investors, Fivarctar ExEcutrve, May, 1971, at 2, 9, 13.

In a statement which the Financial Analysts Federation submitted to the SEC on March 2, 1972, in connection with the hot issues study, they concluded, at 2-3:

There is unanimity of opinion on the part of the Subcommittee that the Commission's rules, regulations, and forms under the Securities Act of 1933 do not result in adequate disclosures that reflect economic reality regarding the business and financial operations of registrants offering new issues, and that the Commission's rules under the Securities Exchange Act of 1934 do not provide adequate protection to investors and, therefore, may tend to foster inappropriate valuations in the market place. . . Rather, the format and content of the offering prospectus is generally inadequate to enable the analyst and/or investor to properly arrive at a decision as to the reasonableness of the offering price relative to the background and potential of the company involved.

43 Address by SEC Chairman Casey, New York Law Journal and the Association of the Bar of the City of New York, Apr. 21, 1972, at 5, 8-9. 
investors and at the same time protect them against improper selling practices-the time has come to opt for more disclosure. It is thus suggested that the traditional ban on soft information in SEC filings be relaxed somewhat when soft information is relevant, material, reliable to an acceptable degree, and adequately qualified in its presentation so that investors will appreciate its soft character. In an area where extremely fine and subtle distinctions are drawn, ${ }^{44}$ this suggestion for change relates primarily to matters of degree, emphasis, approach, and even bias, rather than an outright repudiation and reversal of longstanding policies. As a general principle, the SEC should move slowly and experimentally in permitting (and requiring) soft disclosures.

\section{The Value of a More Flexible Approach}

\section{Increased Responsibility and Reliability}

Certain types of soft information are highly relevant in making investment decisions and, in fact, are commonly used in the securities markets. The inclusion of such information in formal filings, as contrasted with its dissemination through oral sales efforts, is likely to make it more responsible and reliable in the long run. Those who prepare SEC filings tend to be cautious and conservative in what they commit to writing. The inclusion of a statement in a filing would tend to restrain the natural enthusiasm of registered representatives in dealing orally with individual customers. Certainly the distribution of information through a filing, rather than oral selling channels, will expose the distributor to greater liabilities both legally and practically (for example, by simplifying the proof of what representations were made), thereby tending to assure increased reliability.

\section{The Prevailing Approach is Counter-Productive}

The extreme negativism characterizing filings has been counterproductive to the goal of investor protection. When every situation is made to look bad, it is hard to distinguish the truly bad from the moderately bad and, indeed, from the genuinely good. Thus, with all statements of future plans followed by the same pro forma disclaimer-that there is no assurance of success - and with no estimate of the realistic probabilities ever permitted, the value of the warning has become diluted. The situation may be illustrated by one offering within the author's experi-

\footnotetext{
44 For example, the Wheat Report suggested generally that the type of projections which would be prohibited in a prospectus should not be published outside of the prospectus while an issuer is in registration. However, the Report's recommendations would permit public utilities to continue publication during the waiting period of regular and customary estimates of kilowatt hour sales for the forthcoming year, although such projections would be barred from the utility's prospectus. WHEAT REPORT, supra note 2, at $134-35$.
} 
ence in which the company's position had deteriorated between the initial filing and the effective date. The initial filing, following the customary pattern, was so negative that there was no meaningful way to make the warning more emphatic for the final prospectus. Can one be expected to add: "P.S. We really mean it this time."?

\section{The Traditional Approach is Inconsistent with the Basic Disclosure Philosophy}

The general premise of the securities laws is to give investors all relevant information, and rely on them to make their own evaluations. In effect, the traditional view on soft information is based on the paternalistic view that certain investors may misuse such information. The result is that soft information is kept not only from the unsophisticated but also from the highly sophisticated investors who would use it effectively and properly. In effect, the system is tailored to the lowest common denominator of investor sophistication, to the detriment of all others. The benefits to be gained by making more relevant information avaliable to all investors justify the minimal risk that some investors may attach too high a level of credibility to a soft disclosure.

\section{Various Types of Filings Present Different Considerations}

One may concede, arguendo, that highly conservative disclosure is appropriate when the principal users of a disclosure document will be prospective new investors, as in the case of a prospectus for a first public offering. Different standards should apply, however, to periodic reports, proxy statements and, to some extent, 1933 Act registration statements of companies that are already publicly owned. ${ }^{45}$ SEC filings for publicly owned companies provide a reservoir of information which is relied upon both by existing investors who must consider whether to hold or sell the securities, and by prospective new investors. From the viewpoint of the overall trading market, overly conservative disclosure is no more fair to existing investors than is overly optimistic disclosure fair to prospective new investors. ${ }^{46}$ There should thus be a greater

45 Investors in the trading market and analysts may rely on 1933 Act prospectus information, even if they are not purchasing securities in the registered distribution. See Colonial Realty Corp. v. Brunswick Corp., 337 F. Supp. 546 (S.D.N.Y. 1971).

46 Historically, the first task which the Congress delegated to the Commission was that of protecting buyers of securities to whom companies and underwriters offered new issues of securities .... . This has over the years produced a bias toward calling for the utmost conservatism, towards demanding understatement, towards excluding judgments and expressions of opinion in describing a company and its prospects. This approach has been effective in curbing the more exuberant and less responsible promoter, albeit with side effects which have developed a negativism in new issue propectuses which has impaired their usefulness, a condition we are trying to correct by rejecting boilerplate and calling for specific descriptions and expressions of judgments and opinion if they are well based. 
effort" to achieve "fair" rather than "conservative" disclosure in documents which may significantly influence both of these groups.

Consider the irony in SEC v. Texas Gulf Sulphur Co., ${ }^{48}$ a landmark case dealing with inadequate disclosure (albeit not in an SEC filing). There the principal deficiency in a critical first press release was its overly conservative or negative disclosure about the company's mineral discoveries. This undue pessimism caused existing shareholders to sell their holdings and incur losses totalling millions of dollars. ${ }^{49} \mathrm{Al}-$ though bad faith was found on the part of the press release draftsmen, it is easy to imagine how an experienced securities lawyer, dealing under great pressure with a similarly fluid and uncertain situation, would tend as a matter of instinct and tradition toward a very conservative and understated approach in drafting a press release.

\section{The Traditional Approach Underestimates Investors' Capabilities}

The fear has been expressed that investors will attach too much credibility to soft information in SEC filings. This traditional objection to soft information, however, underestimates the capability of investors, who are generally accustomed to dealing with soft information through the normal workings of the trading markets. While blatant puffing is not considered proper under the securities law, investors realize that, within a permissible range, managements may tend to be fairly optimistic, and management opinion can be evaluated in that light. The benefits to be gained by making more relevant information available

But where this historical bias has really given way and where it is of great significance to investor relations people is when it has had the effect of underinforming existing shareholders by withholding from them management's opinions and judgments about the future. These shareholders are not necessarily buyers as are those to whom new issue prospectuses are addressed. They need information which will help them to decide whether to hold what they have or sell. If they are not given a full picture they may sell themselves out too cheaply. Thus, when we put restrictions on management passing along to stockholders information about appreciation in the value of assats, the prospects of new discoveries, the development of new technologies and methods and products, we may be putting existing shareholders at a disadvantage in their investment decisions and dealings with those who are able to acquire realistic information in the market place and elsewhere. Opinion, judgment and all future oriented information calls for prudence and care in developing the factual basis and drawing a conclusion but that is no reason for prohibiting it.

Address by SEC Chairman Casey, National Investor Relations Institute, Oct. 3, 1972, at 2-4 (emphasis added).

In Epstein v. Kearns, CCH FED. Sec. L. REP. I 93,625 (S.D.N.Y., Oct. 2, 1972), a shareholder made the interesting contention that insiders violated the anti-fraud rules when they caused the company to prepare a prospectus with too conservative a description, knowing that the insiders themselves were intended to be major purchasers of the registered securities.

47 See text accompanying note 20 supra.

48401 F.2d 833 (2d Cir. 1968), cert. denied, 394 U.S. 976 (1969).

49 On remand, the district court ordered that those privy to unpublished information pay their profits into a special escrow account for defrauded stockholders. See SEC v. Texas Gulf Sulphur Co., 312 F. Supp. 77 (S.D.N.Y. 1970). 
to a large body of investors justify the minimal risks that some investors may attach too high a level of credibility to a soft disclosure. If the public is told that a company earned $\$ 1.00$ a share last year, expects to earn $\$ 1.50$ for the current year which is nine months complete, and projects $\$ 2.00$ for next year, most investors, and certainly all brokers, should be able to distinguish the degree of credibility for each of the three figures, and appropriately discount the certainty of the short and long term future projections.

\section{Discrimination Against Small Investors}

Public confidence in our securities markets requires that, to the extent practicable, all investors have equal access to available information, with no preference for large investors or institutions..$^{50}$ Under prevailing practice, however, if there is a story of economic reality to tell based on soft information which does not appear in a prospectus, it is most likely that the large customer will be given first preference in receiving supplemental information as part of routine selling activity. To the extent that soft information is going to be used properly in connection with selling activity, it should be included in the prospectus so as to be available on an equal basis to all investors.

\section{Guidelines for Future Policy}

\section{A. Mandatory vs. Permissive Disclosures}

In developing a new approach to soft information, different policy considerations underlie mandatory and permissive disclosures. Notwithstanding frequent statements that SEC filings require "full disclosure" of all relevant information, it is quite clear that a filing need not "state every fact about stock offered that a prospective purchaser might like to know or that might, if known, tend to influence his decision . . . ."51 In order to comply fully with the filing requirements, disclosure must be made only of information required by the particular disclosure form, or necessary to make the statements made not misleading, that is, to avoid half-truth. ${ }^{52}$ While the half-truth prohibition is often interpreted

50 SEC v. Glen Alden Corp., CCH Fed. SEC. L. Rep. \ 92,280 (S.D.N.Y. 1968); SEC, Statement on the Future Structure of Securities Markets (Feb. 2, 1972), reprinted in 137 BNA Sec. Reg. \& L. Rep. Part II; New York Stock Excrinnge Company Manual A-20 (July 18, 1968).

51 Otis \& Co. v. SEC, 106 F.2d 579, 582 (6th Cir. 1939).

52 See, e.g., 15 U.S.C. $\$ 77 \mathrm{k}$ (a) (1970), Rule 408, 17 C.F.R. $\$ 230.408$ (1971) (relating to registration statement); Securities Exchange Act of 1934, 15 U.S.C. \& 78a et seq. (1970) [hereinafter cited as 1934 Act], Rule 14a-9, 17 C.F.R. \& 240.14a-9 (1971) (relating to proxy statements); id. Rule 12b-20, 17 C.F.R. \& $240.12 \mathrm{~b}-20$ (1971) (relating to other 1934 Act statements and reports). Little significance attaches to the variations in wording among the many prohibitions against half-truths. 
quite broadly-sometimes excessively $\mathrm{so}^{53}$ - the law has not approached the point that all relevant information must be disclosed in SEC filings. There are various types of clearly relevant soft information which need not (and indeed often may not) be disclosed.

As a matter of sound jurisprudence and, to some extent, constitutional due process, mandatory disclosure requirements should meet three criteria which require the drawing of essentially arbitrary lines in determining what must be disclosed. First, information should not be required unless it can be anticipated that the vast majority of companies can supply such information with a reasonable degree of reliability. It would otherwise be unfair to subject companies to the liabilities of deficient information. For example, it would be unfair to require a disclosure in all cases on matters which are highly subjective (e.g., the relative skill of management), or where hard data may be unavailable to the company (e.g., its share of the overall market).

Second, legal requirements in any field should be articulated with a reasonable degree of specificity, and the degree should increase as the consequences of breach increase in seriousness. Even now, the mandatory requirements, as reflected in the official forms as well as supplemental guides, are rather vague in their present form. In view of the very severe civil and criminal sanctions for violating SEC filing requirements, a high order of clarity about these requirements is appropriate. $^{54}$

Third, very specific disclosure requirements would not serve the public interest if they required information which would merely clutter the majority of filings with irrelevant and confusing detail, in order to catch an occasional material disclosure in an isolated situation.

In view of these considerations, there are practical as well as policy limitations on the extent to which disclosures of soft information can be made mandatory for all companies subject to a particular filing requirement. In contrast, to the extent soft disclosures are made permissive, there will be no need to specify precise topics for disclosure

53 The Staff has shown some tendency to overuse the half-truth approach. On occasion it requests additional disclosures which either fit within exceptions to the stated disclosure requirements (created either expressly or more often by negative inference), or which have no apparent relationship to statements otherwise made or required to be made in a filing. For example, Instruction 1 to Item 17 of Form S-1, relating to management remuneration, clearly indicates that no information about compensation of an officer need be given for any portion of the year specified during which such person was not an officer. A recent comment letter in the author's experience, however, expressly requested information on an individual's remuneration for a period of time after his bona fide resignation as an officer. See also the discussion of the Franchard case, note 91 infra $\&$ accompanying text.

54 But see United States v. Pope, 189 F. Supp. 12, 20-21 (S.D.N.Y. 1960) which held that the requirements of Form S-1 were not unconstitutionally void for vagueness for failure to define the terms "transactions," "party," "interest," and "material." 
since, by hypothesis, disclosure will be made at the company's election. Different policy questions arise, however, in connection with permissive disclosures, such as whether the information is relevant, material, reliable to an acceptable degree, and adequately qualified so that investors appreciate its soft character.

Accordingly, there should be a different standard for mandatory and permissive disclosure in evolving a new approach to soft information. ${ }^{55}$ As in the past, disclosure should be mandatory, and adverse consequences should attach to nondisclosure, only if the information is fairly specific, objective, and negative in character. ${ }^{56}$ But soft disclosure should be permissive on a broader basis, so long as it meets the other standards discussed herein. The result may be some unevenness in disclosure, in that soft information may be permitted, and consequently included, in filings where it is favorable, but equivalent information may not be required, and therefore may not be included, if it is unfavorable. Nevertheless, on balance the results would appear to be desirable, if the net result would be to give investors additional, useful information.

Such a development would not be a major departure from generally prevailing practice. Even today, companies have broad discretion in selecting information to be included in their filings, beyond the mandatory material. Quite commonly in fact, once a company has made the

55 The Franchard case, discussed in note 91 infra, illustrates an application of this double standard. Unquestionably the prospectus might have stressed the company's unique dependence on its founder, but its failure to do so was not alleged as a deficiency.

56 See Prettner v. Aston, 339 F. Supp. 273 (D. Del. 1972) (no need to speculate about adverse labor developments which might result from an acquisition).

"Negative" may be judged in part from the point of view of the party creating the disclosure document. In the context of a conventional prospectus which is directed toward prospective purchasers of an issuer's securities, "negative" information is information that reflects adversely on the issuer. In the context of an exchange offer or tender document originated by a party attempting to purchase securities of an issuer, "negative" information in this sense would be information that reflects favorably on the value of the securities sought to be acquired. In point of fact, many anti-fraud cases dealing with the adequacy of disclosure involved parties attempting to acquire securities who suppressed information which reflected favorably on the investment value of the securities sought to be acquired-e.g., Feit v. Leasco Data Processing Equip. Corp., 332 F. Supp. 544 (E.D.N.Y. 1971) (non-disclosure of the amount of "surplus surplus" of an insurance company sought to be acquired); Gerstle v. Gamble-Skogmo, Inc., 298 F. Supp. 66 (E.D.N.Y. 1969) (non-disclosure of the fact that assets of the target company had a market value substantially in excess of its book value, and that the purchaser of the securities intended to realize the market value through liquidation); Speed v. Transamerica Corp., 99 F. Supp. 808 (D. Del. 1951) (same), aff'd, 235 F.2d 369, 373 (3d Cir. 1956).

If a company is using a registration statement to offer recision to existing stockholders, theoretically those offerees may be unfairly induced to sell their shares if the company is presented in an overly negative light. Perplexing and subtle problems arise when a speculative company in the process of making its first public offering discovers that it must make a concurrent registered recision offer to existing shareholders who have purchased their shares in transactions violating $\$ 5$ of the 1933 Act. Typically, the issuer will use essentially the same prospectus for both the new offering and the recision offering, possibly with an alternate cover page. If the prospectus follows the usual negative approach, the issuer might well be defrauding the recision offerees. 
minimum mandatory disclosures, it puts its "best foot" forward and develops new areas of information in a filing only if the information is reasonably favorable. Of course, as is currently the case, the prohibition against half-truths provides the SEC and the courts with a highly flexible means $s^{57}$ to prevent the suppression of truly significant adverse soft information. Additionally the natural restraints on inclusion of any soft information (for example, the desire to avoid liability) should discourage the excessive use of soft information, even if it is favorable and permissive. In the last analysis, the different standards for permissive and mandatory disclosure suggested herein should result in more balanced information than we have today.

\section{B. Avoiding Retroactive Applications}

The SEC and the courts should avoid the potential inequities of retroactive application of new standards. Many of the changes suggested herein can evolve through interpretation and a shift in approach, without the need for clear-cut revisions in the specific requirements of disclosure forms. If the adequacy of a filing must be judged, the determination should be made in accordance with the standards prevailing at the time of the filing, not more sophisticated standards developed in the interim..$^{58}$

There are various means to avoid retroactivity. The SEC has broad discretion in determining when to commence administrative or civil court proceedings, and in referring cases for criminal prosecution. Furthermore, courts have broad discretion in granting injunctive re-

57 The half-truth approach can be a useful means to an end, once it is decided that disclosure should be compelled. However, it must be recognized that the Commission and the courts have adopted varying standards, depending on the circumstances and subject matter, in determining whether a statement is materially incomplete. A very expansive application of the half-truth prohibition is illustrated by the Franchard case, discussed in note 91 infra, where the mere mention of a man's name constituted a halftruth without disclosure of further information bearing on his integrity. By contrast, the half-truth approach is virtually ignored when no objection is made to the typical prospectus statement that the offering price was determined "by negotiation," with no indication of the basis of the negotiation. This point is discussed at text accompanying note 91 infra. The half-truth analysis is also given very limited application in connection with use-of-proceeds disclosures.

58 For example, as investor interest grew in environmental and civil rights issues, a new disclosure policy emerged without any change in the filing forms. SEC Securities Act Release No. 9252 (July 19, 1971). Arguably the policy merely codified the preexisting obligation of full disclosure. However, it is suggested that any judgment concerning the adequacy of a filing regarding environmental matters (e.g., in applying the half-truth or materiality tests), should give due recognition to the change in the standard of required disclosure occasioned by the publication of the policy. Likewise, the new disclosure requirement relating to compensating balance arrangements which is apparently emerging, see note 19 supra, should not be given retroactive application.

The Commission itself has, on occasion, promulgated interpretations of existing requirements on a prospective basis, in order that the interpretation may be assimilated without undue hardship as to completed or pending transactions. SEC Accounting Series Release No. 130 (Sept. 29, 1972) (dealing with pooling-of-interests accounting). 
lief. ${ }^{59}$ Even in the context of a civil damage suit, in applying the tests of materiality and reliance, and in determining whether a statement was a misleading half-truth, courts should consider disclosure standards prevailing at the time a statement was made in determining what degree of disclosure an investor was entitled to expect. ${ }^{60}$

\section{Different Treatment for Affirmative and Negative Information}

There is some policy justification for a disclosure standard oriented primarily toward protecting investors against purchasing or holding securities which are worse than the investors think (and against selling securities which are better than they think). Relatively speaking, it seems less important to protect them against missing favorable opportunities. In dealing with mandatory (as contrasted with permissive) disclosures, there should continue to be a greater obligation to make disclosure if the information is negative than if the information is affirmative, other things being equal.

\section{SPECIFIC SUggestions}

Having reviewed various general considerations, let us consider certain specific areas in which there should be a reappraisal of the traditional views regarding soft information. Broad categories of information will be identified where relaxation of the traditional exclusionary rules seems indicated, but in most instances no attempt will be made to suggest the precise quantum of change.

\section{Plans and Expectations}

Investment decisions cannot be made as of a prior date. The past is prologue. Disclosure documents containing historical data are useful (if at all) primarily as a means of helping investors evaluate future prospects. Nevertheless, filings have traditionally excluded a vast reservoir of information which is highly relevant in predicting future developments-namely, the plans and expectations of the company's management. In the normal course of business, management prepares budgets and makes projections concerning financial results such as sales, expenses, and profits. In addition, management often develops or has

59 See, e.g., SEC v. Harwyn Indus. Corp., 326 F. Supp. 943 (S.D.N.Y. 1971) (finding a violation but denying preliminary injunction sought by SEC because of uncertainty in law prevailing at time of activity in question).

$60 \mathrm{Cf}$. Dolgow v. Anderson, 53 F.R.D. 664 (E.D.N.Y. 1971), aff'd per curiam, 464 F.2d 437 (2d Cir. 1972). The industry turmoil which can result from a retroactive change in prevailing standards is illustrated by the difficulty which the court had in formulating its final opinion in Chasins v. Smith, Barney \& Co., Inc., 438 F.2d 1167 (2d Cir. 1971). 
available many other types of forward-looking information, not relating specifically to financial results, regarding such matters as (1) plans for its products, marketing program, methods of financing, personnel, or general business strategy; (2) plans for the expansion, contraction, or redirection of the business; (3) plans for acquisitions of other companies, which may or may not have been specifically identified; or (4) plans involving the disposal of existing assets, which may include a reasonable expectation that the assets will yield proceeds far above (or below) the carrying value on the company's books.

Considering the critical importance to investors of information bearing on future developments, a balance of policy considerations dictates an increase in forward-looking or predictive information in filings concerning the reasonable expectations of management, and the basis therefor. A good business executive normally has some firm expectations about the immediate future of his company. To the extent that uncertainties exist, he should be able to pinpoint the major contingencies which could affect the future and estimate the probabilities of various possible results. Experience with annual reports and other non-filed communications from companies to investors indicates that managements are capable of generating a good deal of reliable forward-looking information. Indeed, if a company's management did not have some fairly definite and well-based expectations about the future, that fact itself would be important for investors to know.

There are, however, two considerations militating against disclosure of plans and expectations. While these factors should be considered in tailoring the specifics of a new disclosure approach, they are not so significant that the status quo should be retained. First, there is the risk that managements will feel pressure to make business decisions which will result in the fulfillment of earlier predictions, even though different decisions would appear to be more appropriate. However, the very fact that his company becomes publicly owned may tend to restrict management alternatives. Managements now make predictions through nonfiled means, and any additional pressure to fulfill a prediction because it is contained in a filing is only a marginal consideration. ${ }^{61}$

61 Generally, the management of a well-run company does not make day-to-day decisions with regard to anticipated impact on the market price of its securities. However, a company does have some legitimate interest in the market price for its securities, for example, if it is making acquisitions for its securities. There may be certain types of management decisions-such as the strategy to adopt in a labor negotiation when a strike is threatened-where the impact on the market price for company stock could be a proper consideration.

"In August 1969, when an Arthur Andersen audit showed Four Seasons hadn't reached its earnings projections, [two Company officials] allegedly manufactured millions of dollars of false and nonexistent construction costs. The indictment said Arthur Andersen ... overlooked the falsity of the costs and certified Four Seasons financial state- 
Second, mandatory disclosure about future plans may put a company at a disadvantage vis-à-vis its competitors. The frequently heard complaint that disclosure will adversely affect a company's competitive position is often exaggerated. The author has known of few if any instances where significant adverse developments resulted from disclosure, despite dire predictions to the contrary. However, such a result may be more likely to occur when a company must disclose its future plans, strategies or expectations, as contrasted with historical data. Many companies now find that a public financing cannot proceed when critical developments are in progress and adequate disclosure is impossible or inappropriate. For example, an offering is frequently deferred until a pending material acquisition is either completed or abandoned. Unfortunate though this may be to the particular company, it is a necessary consequence of our disclosure system. The possibility of some competitive disadvantage in isolated cases is not a factor which should preclude all mandatory disclosures about future plans.

Occasionally the Staff's hostility to soft information concerning the future prevents investors from learning information that may be very useful in evaluating a company's future. Staff comments are often designed to focus the prospectus reader's attention primarily, if not exclusively, on where the company has been, and not where management hopes to take it. Even if all of the risks and contingencies are adequately disclosed, the Staff tends to object in principle to lengthy discussions about the future. The attitude seems to be: just tell us where you have been, not where you expect to go. ${ }^{\mathbf{2}}$

Comment letters occasionally request deletion of a statement because it contains an "implied prediction," without offering any further basis for the request, apparently relying on the unstated premise that everyone knows prospectuses should be untainted by predictions, im-

ments based on the false data, knowing they were false." Wall St. J., Dec. 21, 1972, at 3 , col. 2 .

62 The point can be illustrated by the author's experience with a prospectus of a company which historically had manufactured specific products for a rather narrow market. The prospectus indicated the company's plans to concentrate marketing efforts toward a different type of customer for the same product (an effort in which it had already achieved some success), to use its technology in designing similar products for totally different markets (an activity to which considerable marketing effort had already been directed with some significant indication of potential customers, although no sales), and to develop a completely new product line (which had already gone through an extensive pre-production phase). With each reference to these future plans, there was a disclaimer indicating that success was not assured. A very substantial portion of the proceeds were being allocated to these new activities. The comment letter made various requests to delete or condense discussions of the company's future plans. The comments were directed at material which accounted for approximately three pages of a 49 page prospectus. The objection was not directed to the absence of warnings concerning the risk. Rather, it was an objection in principle to the amount of text devoted to the company's future plans, as contrasted with its history. The matter was finally resolved on a satisfactory basis after discussion with the Staff, but the incident is illustrative of the Staff's instinctive bias. 
plied or otherwise. If a statement meets appropriate standards discussed herein, however, it should not be considered objectionable per se because of its predictive character.

When management has a strategy for the future, it should be free to explain fully its "game plan" and to give its realistic analysis of the probabilities and contingencies for its success. If it plans to redirect the company's activities, information bearing on the risk/reward potential of the future program can be more relevant to a new investor than would be a discussion of the past. Of course, discussions of future plans should be qualified to point out the risks and uncertainties.

There should be no objection in principle if optimistic overtones color management's analysis of its forward-looking program. Investors should expect management to have favorable attitudes toward its own program. It is preferable to give the public a realistic indication of management's favorable view, trusting the investor to discount the information appropriately, rather than to end every discussion with the boilerplate (and essentially useless) reminder that "there is no assurance of" the world's continued existence.

\section{A. General Principles}

In reshaping attitudes and approaches toward predictive statements, certain general principles, applied on a common sense basis, should provide investors with more useful data.

\section{Reasonable Basis for Predictions}

Predictions should have a reasonable basis and should represent the honest good faith expectation of the party making them. ${ }^{.3}$

\section{Disclosure of Assumptions}

To the extent practicable, the major assumptions and bases underlying predictions should be articulated, especially if they involve a significant departure from the status quo. If a prediction is based primarily on the subjective judgment of management, rather than on objective data, investors should be so advised. Once investors know the basis for a prediction, they should be able to assign an appropriate credibility factor to the prediction.

The company should be prepared as well to support the reason-

63 It is often said in the related context of broker-dealer disciplinary proceedings, that the predictions should have a reasonable "factual" basis. It is suggested that the need for a "factual" basis be deemphasized, to the extent that the term "factual" implies that there must be hard, objective data from which others could deduce the same conclusion. In point of fact, major business decisions often are made on the basis of the judgment or intuition of experienced executives who do not have hard evidence at hand. 
ableness of the assumptions underlying its predictions. However, the burden imposed on the company should be relatively higher when the company has a unique ability to justify or evaluate an assumption, and should be relatively lower when the assumption relates to a matter of general knowledge. Thus, if a company bases its prediction upon the assumption that prime interest rates will rise (or fall) sharply within the next year, investors generally are able to evaluate the soundness of that assumption. It should be sufficient for the company to show that its view was held by a respectable number of authorities, without imposing upon the company the need to develop a basic economic analysis on projected interest rates. Alternatively, the burden on the company to justify its assumptions should be greater if, for example, the assumption underlying the prediction is that the company's products will comply with highly technical specifications.

\section{Capability of Achievement}

Statements of future plans should be limited to those plans that the company is reasonably capable of achieving within a reasonable time period. ${ }^{64}$ For example, if the company has virtually completed a research and development program on a new product, and it is reasonably convinced that the product will be commercially successful, it would be justified in discussing its plans for the introduction of that product. By contrast, if the company is just beginning a long term research and development program, with the ultimate outcome still largely speculative, it would be inappropriate to discuss a present "plan" to introduce the product. The company might, however, appropriately discuss the nature of its research and development program.

\section{Commitment}

A plan should not be discussed unless the company has substantially committed itself to the particular course of action. If a plan is of the type that requires approval by the board of directors, it should be discussed in a filing only after the board has approved it and undertaken the commitments, such as funding, necessary for its implementation. ${ }^{65}$

64 See SEC Securities Act Release No. 4936, I 52 (Dec. 9, 1968): "Unless there is reasonable assurance that the securities to be offered will be acceptable to a securities exchange for listing, the prospectus may be misleading if it conveys the impression that the registrant may apply for listing of the securities on an exchange or that the underwriters may request the registrant to apply for such listing."

65 This principle has been established in cases dealing with the question whether plans are sufficiently definite to require disclosure. See, e.g., Allen v. H.K. Porter Co., 452 F.2d 675 (10th Cir. 1971) (plan to refinance a target company too indefinite to require disclosure); Susquehanna Corp. v. Pan American Sulphur Co., 423 F.2d 1075 (5th Cir. 1970) (plan to merge company too indefinite to require disclosure); James Blackstone Memorial Library Ass'n v. Gulf, M. \& O.R.R., 264 F.2d 445 (7th Cir.), cert. denied, 361 U.S. 815 (1959) (plan to sell assets too indefinite to require disclosure); 
Such commitments need not be absolute; where they are subject to contingencies, such contingencies should be disclosed in the filing.

\section{Disclosure of Predictive Character}

Predictive statements should be cast in terms of management's "present plans," "present expectations," or a similar verbal formula which will make clear to investors the predictive nature of the statements. Statements of what the company "will" do should be used only when there is a high degree of assurance that the company can and affirmatively intends to accomplish the particular result. ${ }^{66}$

\section{Estimate of Probabilities}

Companies should indicate some realistic estimate of the probabilities of success. The statement should be cast in general qualitative terms, rather than specific quantitative terms unless a firm basis exists for a higher degree of precision. It may be useful to remind investors that there is no assurance concerning the realization of a prediction, but a pro forma disclaimer of assurance, without more, attached to the end of every predictive statement, is not as useful to investors as management's realistic appraisal of the probabilities.

\section{Accuracy of Prior Predictions}

Whenever possible, filings should disclose management's prior prediction record. Especially when further predictions are to be made on the same subject, a comparison should be made between the actual results achieved and earlier predictions of those results. Of course, if past predictions have proven to be inaccurate, management should be permitted (and possibly required) to explain its view of what caused the discrepancy.

Whenever management is called to account for its forecasts, the adequacy of any prediction should be determined in light of the information known or reasonably available to the person making the prediction at the time it was made. ${ }^{67}$ The fact that a prediction turns out

SEC v. Bangor Punta Corp., 331 F. Supp. 1154 (S.D.N.Y. 1971) (same). The issue is typically framed in terms of whether or not the undisclosed information was "material." See Radiation Dynamics, Inc. v. Goldmutz, 464 F.2d 876 (2d Cir. 1972).

In SEC v. Shapiro, CCH FED. SEC. L. REP. I 93,623 (S.D.N.Y., Sept. 28, 1972), the defendants were held to have violated the anti-fraud rules by their purchase of stock while a merger negotiation was pending but before the facts were publicly disclosed. The court held that the information regarding the negotiations were material facts and that the defendants' purchases constituted a violation of the anti-fraud rules even though the merger did not ultimately take place. At the time of the defendants' purchases, "the proposed merger could be considered a viable possibility." Id. at 92,850 . 66 See 1933 Act Rule 407(c), 17 C.F.R. \& 230.407(c) (1971).

67 Dolgow v. Anderson, 53 F.R.D. 664 (E.D.N.Y. 1971), afj'd per curiam, 464 F.2d 437 (2d Cir. 1972); Republic Technology Fund, Inc. v. Lionel Corp., 345 F. Supp. 656 
to be inaccurate should not, of itself, indicate that it was improperly made, although subsequent development may have a bearing in determining what information was or should have been known at the time of the prediction. Nor should the fact that a prediction is fulfilled necessarily indicate that it was reasonably based-an unwarranted prediction of a market price increase may be realized, for example, precisely because a manipulative scheme succeeded. ${ }^{68}$

\section{B. Financial Projections, Budgets, and Appraisals}

Projections and forecasts of financial results-such as budgets or projections of revenues, expenses, and earnings-are a special category of forward-looking information highly relevant to investors. Indeed, expected earnings per share in the immediate future is among the most significant factors influencing securities prices and, consequently, investment decisions. Projections of this nature are widely used in the financial community, and the existence of an earnings projection has been considered as a material fact in applying the anti-fraud provisions. ${ }^{69}$ Investors generally are aware, from common experience, that forecasting is not a particularly accurate technique, and that errors are most often on the optimistic side. Investors are in a position to weigh the credibility of forecasts. The possibility that a particular investor may attach too great a significance to a forecast certainly does not justify keeping this whole category of information out of all filings.

The extent to which financial projections should be included in filings presents an extremely difficult and specialized subject about which a considerable body of opinion has developed. ${ }^{70}$ However, al-

(S.D.N.Y. 1972) (interim unaudited financial statements prepared on basis of facts known at the time were not deficient, although subsequent year-end adjustments were made).

68 Kahn v. SEC, 297 F.2d 112 (2d Cir. 1961); Chris-Craft Indus., Inc. v. Piper Aircraft Corp., 337 F. Supp. 1128 (S.D.N.Y. 1971).

69 SEC v. Lum's, Inc. (S.D.N.Y., Nov. 9, 1972) (consent injunction), reported in 177 BNA SEC. REG. \& L. REP. A-8 (Nov. 15, 1972); SEC v. Glen Alden Corp., [19671969 Transfer Binder] CCH FED. SEc. L. REP. [I 92,280 (S.D.N.Y. 1968); Merrill Lyach, Pierce, Fenner \& Smith, Inc., SEC Securities Exchange Act Release No. 8459 (Nov. 25, 1968), in [1967-1969 Transfer Binder] CCH FED. SEC. L. REP. I 77,629. For cases holding inadequately-based projections actionable, see Sprayregen v. Livingston Oil Co., 295 F. Supp. 1376 (S.D.N.Y. 1968); Taylor v. Janigan, 212 F. Supp. 794 (D. Mass. 1962); SEC v. F.S. Johns \& Co., 207 F. Supp. 566 (D.N.J. 1962). Investors tend to give undue emphasis to reported earnings as a measurement of value. It might be argued that wider use of earnings projections in disclosure documents is undesirable simply because it will focus greater attention on them.

70 In SEC proceedings on hot issues numerous witnesses discussed forecasts; see SEC, In the Matter of Hot Issues Securities Markets, Ad. File No. 4-148 (Mar. 22, 1972) [hereinafter cited as Hot Issues]. Also, the Commission has recently held hearings relating to the use of estimates, forecasts, and projections in filings. See SEC Exchange Act Release No. 9844 (Nov. 1, 1972). In Rieling \& Burton, Financial Statements: Signposts as Well as Milestones, Harv. Bus. REv., Nov.-Dec. 1972, at 44, the traditional arguments against forecasts in filings are balanced against competing considerations, and the authors conclude that forecasts should be included in filings. Significantly one of the co-authors of the article is presently the Chief Accountant of the SEC, although the 
though views on the specifics vary widely, a consensus may be forming that at least some types of financial projections should be allowed in certain filings. ${ }^{71} \mathrm{~A}$ detailed analysis of such considerations is beyond the scope of this Article. However, the following principles are offered as a practical guideline for the increased disclosure of soft information. Although in some instances these guidelines restate the general principles given above for dealing with any predictive statement, there are added factors in financial projections that require a separate analysis.

1. Financial projections should be includible in filings only if there is a reasonable basis for the projections. ${ }^{72}$ Generally, the projection should be based on past performance or other hard data, such as an existing backlog of orders for the company's products. If a start-up company has not yet developed a commercially salable product, normally it should not be permitted to project a full income statement, since there would be no basis for projecting any specific level of sales. Projections even for an active operating company should normally be confined to a reasonably short term period-the balance of the current fiscal year plus one additional year, for example.

2. Generally the inclusion of projections should be optional with the issuer. Projections should be mandatory only in very narrowly defined circumstances where they can be prepared with a relatively high degree of certainty. ${ }^{73}$

article was largely developed before he assumed that position and there is the usual disclaimer that the article expresses neither his nor the SEC's official view. See also Kripke, supra note 10; Prospectuses, supra note 10 . For a discussion of the experience in England, where company-originated forecasts are widely used, see Grieves, English Profit Forecasts, 5 Rev. SEc. Reg. 919 (1972); Damant, A Note on Practice In the United Kingdom-Financial Forecasting by Companies, 28 FivanctaI ANaLYsTs J., Sept.Oct. 1972, at 44.

71 See text accompanying notes 26-28 supra, discussing the Commission's hot issue proposal on budgets.

72 The Commission's hot issue proposal to require disclosure of "a budget of anticipated cash expenditures and resources ....," see note 28 supra, probably uses the term "budget" to mean this kind of reasonable projection. However, the term may also connote a management tool prepared for internal purposes on a basis not necessarily refiecting management's best estimates of likely results. For example, the budget may be prepared as a goal representing the best possible results which management can reasonably hope to achieve. A management budget may not be internally consistent, although the inconsistencies may not necessarily be apparent to those who prepare the budget. For example, the budget may include a substantial sales increase but may allocate the same expenses to the department handling raw materials, without focusing on the fact that a substantial sales increase would increase indirect costs in the materials handling department.

In order to avoid confusion with such internal budgets, it is suggested that any SEC requirements for forward-looking financial information be expressed in terms of a "forecast," a "projection" or some other term that clearly implies management's best estimates of likely results unless, as some commentators have suggested, the requirement is actually intended to disclose management's goal. See, e.g., statement of Harvey Kapnick, Chairman of Arthur Andersen \& Company, Hot Issues, supra note 70, at 4-5. In the latter event, however, the disclosure should be clearly qualified so that the investor can distinguish the budget from a forecast of most likely results which may be (but need not necessarily be) quite different.

73 For example, if an investment relates solely to interests in a building which is 
3. The major assumptions underlying the projection should be set forth, but it should not be necessary to detail pages of specific assumptions, especially if they relate to the reasonably based expectation that the status quo will continue. Furthermore, when it is possible to do so, the issuer should try to evaluate the extent to which a deviation from the assumed fact can affect the projected results, since even a minor variation in one assumption may have a major impact on the projected results, and vice versa.

4. To the extent practicable, auditors or other experts should expertize, or at least give negative comfort on, ${ }^{74}$ the arithmetic calculations as well as the adequacy and consistency of the accounting principles used in formulating the projection. ${ }^{75}$ However, the experts should not be required to pass affirmatively on the soundness of the assumptions. To do so would very likely take them beyond the area of their expertise, might well involve undue expense, and could conceivably taint their independence when they later audit the period covered by an earlier projection.

5. There are cases where it would be wise to permit (or require) projections of only certain income or expense items, instead of a full income statement. For a start-up enterprise still in a development phase, without commercially salable products, it might be most realistic to project certain expenses (for example, those which are fixed and not dependent on sales) over the next year, without projecting any level of revenue. ${ }^{76}$ By contrast, a well-established utility may find it easier to project revenues than to project expenses or profits, since the demand for service and the rates to be received may be relatively more certain than the level of expenses and the resulting net profits. ${ }^{77}$ In other cases,

occupied under a long term net lease by a triple-A tenant, it might be appropriate to require a financial projection based upon the stated assumption that the tenant will fully perform its obligations. Cf. Form S-11, Item 6(b). Tax shelter investments are another category where certain types of mandatory projections-for example, concerning cash flows or tax effects-may be justified.

74 An auditor giving "negative comfort" would state that he has no reason to believe the projection is inaccurate in its arithmetic calculations, consistency of accounting treatment, or in other aspects for which comfort is being given.

${ }^{75}$ An argument has been made against such limited expertizing, on the grounds that forecasts probably depend about $95 \%$ on the assumptions and only $5 \%$ on accounting methods and arithmetic used in compilation. It has been suggested that any association of an auditor with a forecast is likely to imply more than a 5\% responsibility, and that auditors will not be able effectively to avoid responsibility for the assumptions. Hot Issues, supra note 70 , at 12 .

At least two new firms have been organized to function as independent experts in verifying the reasonableness of financial forecasts and the assumptions underlying them. Schellhardt, SEC Pressure to Include Projections in Prospectuses Inspires New Firms, Wall St. J., June 9, 1972, at 6, cols. 3-4.

76 The Commission requires a projection of first-year expenses to be included on Form BD by a new broker-dealer. 1934 Act Rule 15b1-2(c) (3), 37 Fed. Reg. 9669 (1972) (to be codified at 17 C.F.R. \& 240.15b1-2(c) (3)).

77 See WHEAT REPORT, supra note 2, at 134-35. 
the best course would be to frame projections in terms of the relationships among specific variables-for example, to project the levels of unit sales necessary to cover overhead at various unit sale prices-instead of showing a total income statement.

6. Issuers should be permitted to state their projections of reasonable expectations. A presentation in terms of a range is particularly helpful for a company with relatively high fixed cost and low marginal cost, since it will show the change in the profit-to-sales ratio as sales increase or decrease.

7. In judging the adequacy of a projection for purposes of determining liability, the key issues should be whether it correctly stated the good faith view of management and whether it was reasonably based, not whether it proved to be an accurate prophesy. While developments subsequent to the date of the forecast may be relevant, indicating what management knew or should have known, the reasonableness of the forecast should be determined in the light only of such information as was known or reasonably available to management at the time of the forecast. $^{78}$

8. Appraisals based on current fair market value, as contrasted with values based on historical costs, present another type of financial forecast. The extent to which fair market values should be disclosed in addition to (or in lieu of) historical cost data is an extremely complex subject beyond the scope of this Article. ${ }^{79}$ However, it is clear that in at least some circumstances-for example, where there is a definite plan to sell assets at a price reasonably anticipated to differ substantially from historical cost-disclosure of current values is appropriate and in many cases should be mandatory. ${ }^{80}$

\section{USE OF Proceeds}

The use-of-proceeds section of a prospectus represents one of the few areas where soft information has not only been permitted, but to

${ }^{78}$ See Dolgow v. Anderson, 53 F.R.D. 664 (E.D.N.Y. 1971), afj'd per curiam, 464 F.2d 437 (2d Cir. 1972). at 1188.

79 For a discussion of the disclosure of fair market values, see Myths, supra note 10,

80 E.g., SEC v. Bangor Punta Corp., 331 F. Supp. 1154 (S.D.N.Y. 1971); Gerstle v. Gamble-Skogmo, Inc., 298 F. Supp. 66 (E.D.N.Y. 1969); Speed v. Transamerica Corp., 99 F. Supp. 808 (D. Del. 1951), aff'd, 235 F.2d 369, 373 (3d Cir. 1956). In Kohn v. American Metal Climax, Inc., 458 F.2d 255, 265 (3d Cir.), cert. denied, 93 S. Ct. 120 (1972), a proxy statement was held to be materially deficient because it omitted to explain the basis of the valuation of the assets which American Metal Climax acquired from Roan Selection Trust.

For a case alleging violation of the anti-fraud rules for failure to state appraised values, see Swanson v. American Consumer Indus., Inc., 415 F.2d 1326 (7th Cir. 1969) (reversing summary judgment for defendants), on remand, 328 F. Supp. 797 (S.D. III. 1971) (judgment on the merits for defendants for failure to prove injury, reliance, or causation). 
some extent required, since the subject under discussion is the company's financial plans for the future. Even in this area, however, the traditional policies regarding soft information have kept available information of a highly probative nature out of the prospectus.

To illustrate, assume that a company proposes to spend a million dollars on a plant and equipment to produce a new product. A disclosure of this fact would be required in a prospectus under current standards. Assume further that management makes the following three projections about annual sales of the new product: (a) the company will not be able to cover direct manufacturing costs of the new product unless sales reach 8,000 units; (b) the new operation will not absorb overhead and break even, unless unit sales exceed 13,000; and (c) management projects sales of 25,000 . All three of these projections, as well as the unit sales price used in making them, would be highly informative in making investment decisions- to the professional analyst familiar with the industry, if not to all lay investors. Indeed, if a company incurring such capital expenditures did not have projections of this general nature, that fact in itself would be highly relevant to investors. The three projections could be most useful in estimating the likelihood and extent of success of the new venture, and in generally evaluating the risk/reward potential of the company's financial plan.

A use-of-proceeds section making disclosures of the type suggested by the three projections above would be very rare indeed. Investors typically receive raw data about dollar allocations, but very little information concerning the underlying economic realities necessary to appraise the financial plan. The investor can be misled, of course, by tenuous projections. The hypothetical company should not be able to disclose a five-year profit projection for the new plant. But as was shown in the discussion of analogous problems in the disclosure of forward-looking information, the application of practical guidelines in this area can reduce the risk of abuse, and justifies further relaxation of the strictures surrounding the use-of-proceeds section. Another constructive approach can be seen in the Commission's hot issue proposal. $^{81}$

81 SEC Securities Act Release No. 5276, at 7-8 (July 26, 1972), proposes a new instruction with additional disclosures for first-time registrants that have not conducted operations for a period of three years. The registrant is required to disclose its plan of operations for the immediate future, including further details on its intended use of proceeds. See note 26 supra \& accompanying text.

However, as was the case with the other hot issue proposals, this proposal is oriented toward high-risk start-up ventures which are exposed to the risk of running out of money shortly after the offering. SEC Securities Act Release No. 5276, at 1-3 (July 26, 1972). The Commission has not made a corresponding proposal to require (or even permit) wellestablished companies to develop similar forward-looking disclosures of their plans for future operations. 
There are two specific aspects in which use-of-proceeds sections can be improved in relation to soft disclosures. The first concerns the pressure for an unwarranted degree of certainty with respect to allocations of funds. The second concerns the artificiality inherent in assigning dollars from specific sources to particular projects.

\section{A. The Pressure for Certainty}

The Staff's comments frequently request registrants to harden disclosures in the use-of-proceeds section, thereby making them unjustifiably specific and detailed. The public can be misled when filings suggest that plans and future programs are more definite than in fact they are. ${ }^{82}$ If plans are still fluid or uncertain, any express or implied representations to the contrary are inaccurate.

Typically a small company going public has a great deal of difficulty in stating with assurance precisely what it will do with the proceeds of an offering. The use-of-proceeds section often covers allocations that may take many months or even years to complete, with certain expenditures necessarily contingent on intervening developments or delayed until other expenditures are completed. It may be extremely difficult for management of a small, chronically undercapitalized company to predict long in advance what the most propitious application of funds will be at a future date. Even a well-managed company may change the allocation of the proceeds many times in the course of preparing a prospectus. After the broad categories have been established, the numbers tend to remain fluid until the final effective date. One frequently feels that if the filing were delayed for another draft, the useof-proceeds section would be revised still further, with the final version being somewhat arbitrary. Issuers typically reflect these uncertainties by including reservations or hedge clauses in their use-of-proceeds sections to preserve flexibility-for example, by leaving portions of the proceeds uncommitted, by describing allocations in a very general way, or by reserving the right to reallocate in the light of future developments. The Staff comments, however, frequently request more definite and specific commitments.

Often, after the offering, management decides that it is in the company's best interest to expend a portion of the proceeds differently than indicated in the prospectus (even if the difference represents only a shift of funds among various stated purposes). Indeed, it is estimated that close to half of the companies making a first public offering use at least some portion of the proceeds in a way not anticipated when 
the prospectus was written.$^{83}$ It is not unusual that a project outlined in a prospectus no longer has a high priority in relation to other current needs for funds, or no longer seems meritorious. For example, if funds were allocated to research, development, and marketing for a new product, and it appears after half of the funds are spent that the product will not succeed, management should not (and normally does not) feel constrained to expend the other half on that product. Sometimes the company desires to complete a particular project stated in a prospectus, but finds other means of financing without using the proceeds of the offering. If a company can arrange better terms to lease capital equipment, or to finance a purchase on a long term basis, it should not feel compelled to buy the equipment for cash, simply because the prospectus allocated funds for such a purchase.

The problem of undue certainty is focused by the relatively new form S-R (applicable to first-time registrants), which requires the issuers to file a follow-up report on its actual application of the proceeds. Unless the company can retain reasonable flexibility in the prospectus, this new form may have a chilling effect on management's initiative. Faced with this requirement, management may feel itself under great pressure to follow the use of proceeds stated in the prospectus, notwithstanding the fact that a bona fide business judgment would dictate a more advantageous use of the funds at the time an expenditure is scheduled to be made.

It has been suggested that more specificity in the use-of-proceeds section of prospectuses is desirable. A countervailing consideration must, however, be recognized. At the time a prospectus is being written, management should not have to pretend that the use-of-proceeds plan is more specific than it really is. Nor should it be bound to follow a stated plan which no longer makes business sense, any more than it should be bound by an internal annual budget which typically undergoes revisions throughout the year. The use-of-proceeds section should do no more than state management's good faith intention at the time the prospectus becomes effective. It should not be viewed as a contractual commitment to new investors that their funds must be spent only as stated, especially when the issuer has a bona fide business reason to depart from the plan. This flexible approach has in fact been the

${ }^{83}$ In some such cases, however, there is no inconsistency between the actual use of proceeds and the language in the prospectus. The prospectus may be expressed in much more general terms than the company's specific plans. Thus, if the prospectus allocated funds to equipment purchases (or opening of sales offices), funds may be spent for such general purpose, although the specific items of equipment purchased (or offices opened) differed from those anticipated when the prospectus was prepared. 
prevailing interpretation of a use-of-proceeds section, ${ }^{84}$ and it should remain so.

The argument that the SEC should require more specificity, and greater adherence to use-of-proceeds sections, to protect the supposed expectations of investors that the proceeds will be used exactly as set forth in the prospectus, overlooks a fundamental element in the investment decision. Presumably an investor who has purchased a company's securities has confidence in its management. When a company must decide whether to spend its funds either in the manner that management currently thinks is best, or in the manner that management thought would be best when the prospectus was written, it seems reasonable, in light of the investor's confidence in management, to allow management's current judgment to prevail. ${ }^{85}$

\section{B. Artificiality}

There is an artificial or fictional aspect about many use-of-proceeds presentations. The disclosure item assumes, to a large extent, that specific dollars derived from the offering can be traced into specific projects, which may stretch over a course of many years. In fact, dollars derived from public financing are fungible economically with dollars from other sources, such as retained earnings, borrowing, or sale of other securities or assets. Even when funds from a given source can be traced into a given bank account and out again to meet a particular obligation, the identity of the specific dollars is more apparent than real.

Quite often, the actual business plan is to combine proceeds of an offering with proceeds from other sources in order to achieve a long range financial goal. In such a situation, it would be realistic and helpful to investors if the use-of-proceeds presentation was in the form of a long range financial plan, rather than an arbitrary attempt to trace specific dollars to particular uses-for example:

Over the next three years we propose to spend $\$ 100$ on expansion, of which $\$ 50$ is allocated to plant, $\$ 25$ to equipment, $\$ 15$ to inventory, and $\$ 10$ to increased working capital. We propose to derive the funds from the following sources: $\$ 40$ from the proceeds of the offering, $\$ 35$ from long term mortgages, $\$ 15$ from short term equipment financing, and $\$ 10$ from internally generated funds. Pending use of the proceeds for

84 See Lester v. Preco Indus., Inc., 282 F. Supp. 459 (S.D.N.Y. 1965).

85 These conclusions presume that management is acting in good faith and for the benefit of the company. 
the foregoing purposes, they may be used for the temporary reduction of short term indebtedness.

If the foregoing represents the company's plan in fact, it should be presented to investors in the terms indicated, rather than pretend that funds from specific sources can be traced to specific uses. There would be, of course, a substantial amount of soft information contained in such a presentation - the expectation that future financing will be available on acceptable terms (if the company does not have binding stand-by commitments) and the implied prediction that it will generate earnings of at least $\$ 10$. To the extent that these sources of funds are not absolutely assured, a hedge should be included to alert the investor to the risk that the company may not be able to implement fully the plan presented. Notwithstanding the potential hazards in this form of presentation, however, investors would be far better informed by seeing the entire expansion program in perspective.

\section{Management}

An appraisal of management is of cardinal importance to investors in making an investment decision, especially when dealing with small or unseasoned companies lacking past performance records. Investors would like to know about such factors as management's integrity, ability, diligence in attending to the business, track record, and the extent to which the company is dependent upon a particular individual or group. However, there are inherent limitations on the ability of SEC filings to convey this information. The dilemma has been recognized by the Commission:

In many respects, the development of disclosure standards adequate for informed appraisal of management's ability and integrity is a difficult task. How do you tell a "good" business manager from a "bad" one in a piece of paper? Managerial talent consists of personal attributes, essentially subjective in nature, that frequently defy meaningful analysis through the impersonal medium of a prospectus. Direct statements of opinion as to management's ability, which are not susceptible to objective verification, may well create an unwarranted appearance of reliability if placed in a prospectus. The integrity of management-its willingness to place its duty to public shareholders over personal interest-is an equally elusive factor for the application of disclosure standards. ${ }^{86}$

Let us consider some of the judgments which can be formed on 
the basis of a close working relationship; we will use four hypothetical company managements as the basis for discussion.

The president of Company $A$ is imaginative, energetic, thoroughly conversant with his business and has the combination of guts, motivation, resourcefulness and greed that makes success likely. However, he is not completely candid, and his egotism makes him so difficult to work for that he has not been able to maintain a strong management team, which may restrain the company's growth rate.

Company $B$ is run by four brothers. Each has had extensive experience with every phase of the business and could hold almost any position effectively, including the presidency. They have a mutually satisfactory allocation of responsibility and work extremely well together.

Company $C$ is run by three cousins. The president is fairly competent. The treasurer, who can hardly count, and the secretary, who can hardly read, are lazy, stupid, uninformed about the business, and constantly bickering. Although the company continues to prosper handsomely because of momentum, the management decisionmaking process is near paralysis, and the company cannot meet changing conditions efficiently.

The two poor boys who founded company $D$ thirty years ago succeeded by watching pennies and cutting costs in a highly competitive business. But they are getting old and tired and will probably relax at the helm after receiving one million dollars each from the proposed secondary offering. Their sons, who are scheduled to take over more management responsibility, are playboys who are jealous of each other, and neither has the sharpness of his father.

An analyst studying each company firsthand would certainly consider these impressions in reaching his evaluation-they might well be critical to his final recommendation, and be included in a written report. To the extent that the laws of defamation or the requirements of good taste precluded specific details, he could use general qualitative statements such as: management creates a very favorable (or unfavorable) impression; it has (or lacks) depth; it appears well suited (or unsuited) to meet changing conditions.

Counsel working on an SEC filing, however, rarely consider it necessary, or even appropriate, for a company (acting of necessity through its management) to appraise its own management along the lines suggested. Soft information of such a highly subjective nature, despite its relevance, is out of place in an SEC filing. If, on the other hand, there is specific, objective information bearing materially on management, such information is generally considered a proper subject 
for disclosure, ${ }^{87}$ and, if adverse, may well be a mandatory subject for disclosure. ${ }^{88}$ Indeed, this is the trend shown in the Commission's proposed expansion of disclosures in the management area, as part of its hot issue controls. ${ }^{89}$

Beyond the general dichotomy between subjective and objective information, very difficult judgments remain in determining when information is sufficiently material or hard to permit or require disclosure. ${ }^{90}$ The questions may be explored further by considering specific attributes of management.

\section{A. Integrity}

Of all types of information dealing with management, the mandatory disclosure requirements are probably most rigorous, and disclosure of soft information most necessary, when information reflects adversely on management's integrity. If there is specific information which ma-

87 Disclosure is permissive, for example, if members of management have been singled out for significant awards, or have held responsible trade association or government positions related to their business.

88 Disclosure probably would be mandatory, for example, if the president of an insurance company had just completed a five-year prison term for insurance fraud.

${ }^{89}$ SEC Securities Act Release No. 5276 (July 26, 1972). The proposals call for additional hard information concerning management personnel, such as their ages, and further information regarding past connections with bankruptcies and criminal proceedings. For persons employed by the registrant less than five years, it is proposed that

a brief explanation should be included as to the nature of the responsibilities undertaken by the individual in prior positions to provide adequate disclosure of the prior business experience. It will be sufficient to give specific information only as to the number of people supervised, salary, size of operation supervised, and similar information. What is required is information relative to the level of his professional competence.

1d. 10. The Commission is apparently groping for objective standards to determine what must be disclosed. Certainly the inclusion of such considerable amounts of detail will lengthen the prospectus. Query, however, whether the specific facts requested may not be more misleading than helpful. The data indicated may well suggest performance capabilities which the individual does not have in his new position. Good performance in a particular job is no assurance that a higher position can be well filled. Indeed, it has been observed that career advancement tends to continue until an individual reaches a position in which he cannot perform effectively. L. PETER \& $R$. HULL, THE PETER PRINCIPLE (1969). The fact that a scientist performed brilliantly supervising a 100-man research department of a large corporation does not necessarily bear on his qualifications to head a new, small company. In point of fact, many unsuccessful high technology ventures were founded by men eminently qualifed in technical fields who performed poorly as business managers.

90 Consider the following two examples dealing with alcoholism. Company $A$ produces high fashion apparel and is entirely dependent on the creative genius of its founder to design the line for each new season. Four months ago he started drinking excessively and for the past two months has been confined to a sanitarium where his response to treatment has been poor. The founder of Company $B$ has had a serious drinking problem for years and has been undergoing psychiatric treatment for the past 30 months. In the first case, disclosure is required to indicate at least the fact that the services of the founder may be unavailable to the company. (Query if the specific reason for such unavailability must be disclosed as well.) In the second case disclosure probably is not required, since the situation is apparently stable and the performance record of the company for more than two years was achieved notwithstanding the president's disability. Between these relatively clear-cut cases, one can imagine an infinite spectrum of variations in which the need for disclosures may be very difficult to determine. 
terially and adversely reflects on management, the half-truth prohibition may be read very expansively to require disclosure ${ }^{91}$ even if the dollar amounts involved are below the $\$ 30,000$ threshold normally required for disclosure of insider transactions. ${ }^{22}$ Disclosure probably is not required if the information is vague, ambiguous, or inconclusive as to basic integrity-for example, where highly paid executives make extensive use of company staff and facilities (the lodge, the private plane, etc.) for personal purposes, openly and to the general knowledge of the board of directors, although such action is prohibited by the company policy manual. (By contrast, if a company executive stole an amount of cash from the company's safe equivalent to the fair value of the improperly appropriated fringe benefits, disclosure probably would be required.)

The materiality, and therefore the need for disclosure, of information reflecting on management's integrity may vary depending on whether the individual involved is still connected with the company. If the dishonest officer has been discharged, one might conclude that his dishonesty, and the reason for his discharge, are not mandatory disclosure items; the information may no longer be relevant (assuming that his past defalcations do not materially impair the condition or prospect of the company, for example, as a result of large uninsured

01 Franchard Corp., SEC Securities Act Release No. 4710 (July 31, 1964), in [19641966 Transfer Binder] CCH FED. SEC. L. REP. I 77,113, at 82,038. For further information about the prospectus in question, see note 103 infra. At the time the prospectus for Franchard was prepared, Form S-1, Part I, Item 20, as then interpreted, did not require disclosure of a management transaction unless it was material to the company as well as to the individual involved. Prior to that time, many serious conflict of interest situations were considered to be beyond the scope of required disclosure items, if the dollar amounts in the transactions were not material to the companies involved-as, for example, where the president of Chrysler Corporation was discovered to have had a previously undisclosed interest in a supplier of hardware to Chrysler. See Cohen \& Phillips, Conflicts of Interest and the Federal Securities Lares, 24 FED. B.J. 321, 326-27 (1964); Thanhouser, The Corporate Counsel's Viezpoint, 17 Bus. LAw. 79 (1961). In Franchard, the contention was made that the transaction was not material to the company because the amounts involved were only a small portion of the company's assets. As an alternative ground for rejecting this contention, the Commission found a material omission because of the reflection on management's integrity.

For purposes of disclosure, distinctions might be drawn between a member of management acting improperly for the purpose of furthering the company's interest (e.g., bribing a building inspector to enable a new plant to open on time) and acting improperly in his own interest (e.g., embezzling money from the company). We live in an imperfect world, in which corporate executives sometimes engage in improper activities in furtherance of corporate interests. Every such impropriety for a corporate purpose should not be considered ipso facto material to investors, especially where the impropriety does not threaten the company with serious adverse economic consequences. Kohner v. Wechsler, CCH FED. SEC. L. REP. I 93,537 (S.D.N.Y. 1972). There are limitations on the extent to which the disclosure provisions of the securities laws should serve as a vehicle for dealing with unrelated social ills. Indeed the Commission's release requiring further disclosures relative to civil rights and environmental matters (SEC Securities Act Release No. 5170 (July 19, 1971)) has been criticized as going beyond legitimate disclosure objectives to serve other social purposes.

92 E.g., Form S-1, Part I, Item 20, Instruction 6(iv). 
financial losses), and making a disclosure may adversely affect the company and its shareholders. ${ }^{93}$ Yet, in spite of the offender's discharge, the fact of his defalcations may still be a material disclosure item if it adversely reflects upon the company's internal controls. ${ }^{94}$

The question may arise whether a filing is deficient for failure to make disclosures on management's integrity, in the situation where the guilty party is the only member of management who knows or has reason to know the facts. The SEC has held that compliance with a filing requirement turns on whether the filing is or is not accurate in fact, and not on whether the parties responsibile for its preparation were guilty or innocent. ${ }^{95}$ Accordingly, the fact that only the guilty member of management knew the facts is irrelevant. ${ }^{96} \mathrm{~A}$ court or the Commission might appropriately relax this approach, however, if only one officer, especially one not key to the company, knew or had reason to know of his own undisclosed defalcation. The issue might be approached in terms of materiality, and a finding made that the particular undisclosed fact was not material.

\section{B. Diligence and Competence}

Disclosure of the degree of diligence and level of competence exercised by directors and officers would require especially subjective judgments in an area where there are no clear standards; ${ }^{97}$ clearly filings cannot appropriately give investors all the information they

93 The problems of public disclosure are illustrated by the recent dilemma of American Airlines, a company which had enjoyed an apparently well-deserved reputation for total management integrity. When it discovered that a middle-level employee had taken extensive kick-backs, his employment was terminated and the company referred the matter to the U. S. Attorney. Top management believed that the company should have been given credit for bringing the affair into the open and taking vigorous action. Instead, the company itself was exposed to scandal, thereby damaging internal morale, the company's relationship with customers and its image on Wall Street. In similar circumstances, many companies take remedial action (or inaction-some do not even terminate the employment of the offending employee) with a minimum of public disclosure. See The American Way?-How a Brash Manager Used Middle-Level Job for His Personal Profit, Wall St. J., Nov. 17, 1972, at 1, col. 6.

94 For example, if the company is a securities dealer, the fact that serious embezzlement could occur without detection might be, in and of itself, a material disclosure reflecting upon the rest of management, since effective internal supervision and controls are essential to a well managed brokerage firm. See, e.g., SEC v. First Sec. Co., 463 F.2d 981 (7th Cir. 1972).

95 Franchard Corp., SEC Securities Act Release No. 4710 (July 31, 1964), in [19641966 Transfer Binder] CCH FEb. SEc. L. REP. II 77,113, at 82,038; Siltronics, Inc., SEC Securities Act Release No. 4700 (June 4, 1964).

96 Franchard Corp., SEC Securities Act Release No. 4710 (July 31, 1964), in [1964-1966 Transfer Binder] CCH FED. SEC. L. REP. đ77,113, at 82,038.

$97 \mathrm{It}$ is sometimes suggested that financial statements speak for themselves as an index of management competence, and indeed there may be a correlation between the competence of management and the historical performance of the company in some cases. However, historical resuits do not always tell the whole story about management competence, especially when dealing with a relatively new enterprise which does not have sufficient history on which to base a determination, 
desire. Directors may be very active, vocal, well-informed, and independent of operating management in directing the company's affairs; or, they may be passive, "rubber stamps" or "figureheads" who exercise very little independent judgment or initiative. Officers vary both in competence and in the degree to which they perform the functions generally associated with their positions, ${ }^{98}$ since titles may be allocated according to seniority or other orders of rank extraneous to functions, especially in family controlled businesses.

It may well be that an experienced analyst making a personal investigation could draw very distinct conclusions regarding the diligence and competence of management. However, these are subjects on which very little disclosure in SEC filings has been required, absent extreme circumstances. ${ }^{99}$ The Commission has noted that the degree of diligence required of directors is a question to be determined under state law; there is much divergence and uncertainty in this area, with the general principles that have evolved furnishing only vague guidance. Accordingly, the Commission has held that it is not prepared to pass generally on the adequacy with which directors perform their duties, although its staff has urged it to do so in at least one case. ${ }^{100}$ An attempt to do so would be basically incompatible with the philosophy and administration of the federal disclosure requirements. "It would either result in self-serving generalities of little value to investors or grave uncertainties both on the part of those who must enforce and those who must comply with that Act." ${ }^{\prime 101}$ The Commission has thus required no disclosure concerning the degree of diligence exercised by corporate directors, except where there is outright fraud, reckless indifference, virtual abdication of responsibility, or where affirmative representations are made by which performance can be tested..$^{102}$

\section{Dependence}

A company's dependence upon a particular member of management, while perhaps not as subjective a question as management's

98 The title of chairman of the board is especially ambiguous in its connotations. The holder of this position may be anything from a retired figurehead, with few functions other than presiding at board meetings, to the active chief executive officer of the company.

99 Somewhat more disclosure might be appropriate when dealing with the independent or noninterested directors of a registered investment company. The Investment Company Act of 1940 specifically contemplates that they will exercise a significant degree of responsibility in protecting an investment company against overreaching by its affiliates. See Mundheim, Some Thoughts on the Duties and Responsibilities of Unaffiliated Directors of Mutual Funds, 115 U. PA. L. REv. 1058 (1967); Nutt, A Study of Mutual Fund Independent Directors, 120 U. PA. L. REv. 179 (1971).

100 Franchard Corp., SEC Securities Act Release No. 4710 (July 31, 1964), in [19641966 Transfer Binder] CCH Fed. Sec. L. Rep. II 77,113.

101 Id. at 82,048 .

102 Id. at $82,046-48$, 
competence, represents another type of soft information about which difficult judgments must be made. Disclosures regarding such dependence are made in certain unusual circumstances-for example, where the company is identified with a notable public figure (such as an entertainer or sports star), where one person has a unique technological competence, or, in a service business, where a key individual has particular personal ties to the company's clientele. Dependence is unlikely to be disclosed, however, by many "one man" companies, where a single individual dominates the management by virtue of his position, his personality, and/or his stock holdings. Even in very large corporations, with professional managers who are not major stockholders, the extent to which the chief executive officer "calls the shots" varies widely. As in the case of judging diligence and competence, however, evaluations in this area are generally far too subjective to be items of mandatory disclosure, barring a unique or special circumstance. ${ }^{103}$

\section{Track Record}

There have been a number of recent suggestions urging more disclosure concerning the performance history or "track record" of management, especially in the context of new or promotional companies. $^{104}$ An analyst making a personal investigation in this area might be able to assemble enough highly relevant information to make his own subjective evaluation. However, it is unrealistic, if not impossible, to require disclosure on this subject by companies in their own SEC filings. Assume that a company founder or key officer has performed particularly well (or poorly) with a prior employer. It would rarely be practical for the current employer to include financial or other detailed information about the officer's prior firm. It could be more misleading than helpful to state, or imply, that the overall results

103 The Franchard opinion is illustrative in this respect. Although the Commission found numerous deficiencies in the prospectus regarding management, and the Staff threw the book at the company and charged still others (see note 100 supra), no deficiency was charged for failure to emphasize what was acknowledged to be a fundamental fact about the offering-that the company, a real estate venture, was organized to exploit the talents, reputation, and management ability of the founder, whose name was in the original corporate title. The only sentence in the entire prospectus which purported to describe his background or qualifications read as follows:

Mr. Glickman, whose address is 501 Fifth Avenue, New York, N. Y. has been President of the Company since its organization and prior to that he was engaged in the creation and development of real estate investment opportunities for more than 30 years, was an investor in real property for his own account and organized and supervised limited partnerships and corporations which acquired real property and interests therein.

Glickman Corp., Prospectus 33 (Oct. 2, 1961). There were other factual statements in the prospectus concerning his shareholdings, remuneration, and relations to specific properties. $I d$. 33-37. Although he was identified as a "parent" of the company, nothing therein stated the company's unique dependence upon his skill or public image.

104 See note 89 supra. 
of the prior firm are attributable to the one person in question, even if he was the chief executive. Nor is it practical, in the normal case, for an SEC filing to extract information about a prior employer that would isolate in a meaningful manner the contribution of a particular former employee. ${ }^{105}$

A new company may be financed by a venture capital group which participates significantly in its management. An analyst may be able to look at the past investments of the group and make some judgments about the group's performance record in selecting potentially successful companies and assisting in their growth. But it is doubtful whether there is an appropriate and generally applicable means for a company's SEC filings to detail the performance record of its venture capital sponsor. It would not be practical, for example, to require an issuer to include in its prospectus the venture capitalist's financial statement, or the financial statements of other companies in the latter's portfolio. Such financial statements in the prospectus of a portfolio company might be more misleading than helpful. Investments in portfolio companies may be carried on the venture capitalist's books at cost; this amount normally would not reflect the success of the portfolio company, and might not reflect its poor record unless a writedown had been required in the carrying value of the investment on the books of the venture capitalist. An increase in net worth of a venture capital sponsor may result from ten successful investments; or it may be attributable to one phenomenonally successful investment despite nine bankruptcies. While factors such as these are theoretically subject to explanation, they raise so many collateral issues that a promoter's performance record does not appear generally to be a subject suitable for discussion in the prospectus of a company the promoter is sponsoring.

Of course, in certain extreme situations, disclosure might be required. If, for example, an individual who is the key organizer and principal executive of a new company organized three similar companies before, each of which ended in bankruptcy, disclosure should be mandatory. ${ }^{106}$ However, short of some specific, relevant, and hard informa-

105 Of course, an employer attempting to verify the qualifications of a prospective new employee would inquire about his prior performance, and might well assemble a great deal of data that would be highly useful in making an evaluation. However, the data are likely to be extremely soft, highly subjective, and subject to many qualifications. Numerous circumstances do, of course, exist when one individual has to evaluate the prior performance of another. The basic point remains, however, that such an evaluation may be so subjective, and the factors underlying it so involved with circumstances extraneous to the current employer, that it would be unrealistic to require (or perhaps even permit) disclosure of prior management performance records in a filing, except in rather unusual circumstances where there is highly specific and material data.

106 See Form 10, Item 6(e)(1), requiring disclosures of bankruptcies within two years before the time of filing. 
tion of that nature, there are inherent limitations in the extent to which filings can or should cover the track record of management.

Disclosure of a past track record may be highly appropriate, however, in situations where the same promoters have organized a series of similar ventures. For example, in real estate development, oil drilling programs, and theatrical productions, it is typical for promoters to constitute each new project as a separate limited partnership. In such cases, the results achieved by earlier comparable ventures may be highly relevant to potential investors in a current project.

In the last analysis, an investor in a new and unseasoned company should know that he is buying something of a pig in a poke with respect to the character of management. In evaluating management, he must rely upon the underwriters to a large extent. Indeed, when dealing with unseasoned issues, one might argue that the past performance record of the underwriter is the track record to be studied most carefully: How successful has it been in selecting companies to underwrite which eventually prosper?

\section{E. Implied Representations}

As suggested, mandatory disclosure requirements for specific and material negative information should be interpreted quite expansively when dealing with various attributes of management, especially integrity. Ultimately, an implied representation of "fair dealing" may develop in the company management area as it has with respect to broker-dealer selling practices. The Commission has developed the implied representation or "shingle" theory that merely by hanging out his shingle, a broker-dealer makes an implied representation to his customer that he will deal fairly. A breach of this implied representation may be actionable. ${ }^{107}$

107 The development of the implied representation or "shingle" theory is reviewed by (former SEC Chairman) Cohen \& Rabin, Broker-Dealer Selling Practice Standards, 29 LAW \& CONTEMar. ProB. 691, 702-08 (1964); see Comment, Current Problems in Securities Regulation, 62 MicH. L. REv. 680, 733-43 (1964). The implied representation of fair dealing has been held to be breached, and broker-dealers' actions have therefore been held to be false and fraudulent, in many situations-for example: (1) where a broker-dealer recommends a security without an adequate basis (violating the specific implied representation that recommendations are made on the basis of actual knowledge and careful consideration of all reasonably available information), SEC Securities Act Release No. 4445 (Feb. 2, 1962), in 2 CCH FED. SEc. I. REP. Iff 22,753-59 (and cases cited therein); Schneider, SEC Filings-Their Use to the Professional, 21 FINANCTAI ANALYSTS J., Jan.-Feb. 1965, at 33; (2) where he charges excessive prices (violating the specific implied representation that his prices are reasonably related to the current market), see, e.g., Charles Hughes \& Co. v. SEC, 139 F.2d 434 (2d Cir. 1943); Duker \& Duker, 6 S.E.C. 386 (1939); (3) where he does business while insolvent (violating the specific implied representation that he is solvent and able to discharge his liabilities and consummate his transactions), see, e.g., SEC v. Kelly Andrews \& Bradley, Inc., 341 F. Supp. 1201 (S.D.N.Y. 1972); Finchley Investors Corp., SEC Securities Exchange Act Release No. 7416 (Sept. 8, 1964). 
The implied representation rationale could be applied easily to the corporate management area, providing an effective way of imposing disclosure obligations. It could be held that by offering its securities to the public (or by soliciting proxies), a company makes an implied representation that its management has dealt (and will deal?) fairly with the company and the investors. It would be quite consistent with the trend of the law to have such an implied representation cover matters of honesty. The representation might be interpreted more broadly-for example, to cover matters of diligence, loyalty and, in extreme cases, even competence. Indeed, the implied representation approach has already been suggested as a means of regulating insider trading in securities. ${ }^{108}$

\section{Pricing of a FIRst Offering}

As the result of Staff comments, it has been customary for a prospectus cover page for a first offering to characterize the offering price as having been determined "arbitrarily." Applying customary standards of full disclosure, such a statement, hiding as it does much more than it reveals, is a classic half-truth. ${ }^{109}$ Typically, the public offering price for a first offering is determined by detailed reference to variables such as past and projected earnings, net worth, and return on capital. Each factor is minutely evaluated in comparison with similar companies. There is frequently considerable discussion, highly revealing about how the parties view the company, in determining which other companies are or are not considered comparable. Additional consideration is given to such factors as evaluations of the industry

108 "A vendor who was known by the purchaser to be well informed on the condition of a company might be held to have represented the security to be 'worth' the price asked." Douglas \& Bates, The Federal Securities Act of 1933, 43 YaLE L.J. 171, 189-90 n.92 (1933). Professor Loss postulates a somewhat more refined implied representation (focusing on the insider as buyer): "The insider's offer to purchase at a fixed price might be deemed to constitute an implied representation that, within reasonable limits, the stated price represents the insider's judgment of the value of the security." 3 L. Loss, Securtines Regulation 1456-57 (2d ed. 1961).

109 Even if the Commission accepts the typical substitute phrase that the price was determined "by negotiation," it prohibits any explanation of the negotiations or the factors considered, so that the statement remains materially incomplete.

As part of its hot issue control proposals, the Commission has proposed further disclosures on the various factors that were considered in determining the offering price for securities in a first offering. SEC Securities Act Release No. 5279, at 3, 6 (July 26, 1972). As indicated previously, see note 32 supra \& accompanying text, the proposal seems to focus on high risk ventures in which the "aggregate value being placed on the outstanding shares of the issuer ... bears little or no relationship to the issuer's assets, earnings or other criteria of value." SEC Securities Act Release No. 5279, at 3 (July 26, 1972). The proposal does not seem to be designed for established companies going public where a relatively high price is justified by historical earnings performance, excellent prospects, a strong balance sheet, high return on capital, or similar criteria that are in fact the subject of pricing negotiations. 
(its past trends, long range prospects, and interest to investors) and the management of the company.

The method of pricing an offering may involve extremely soft information. However, it is likely that in many cases a transcript of the negotiations on final pricing would be far more informative to an investor than the final prospectus. (It is not suggested, however, that such a transcript is a practical alternative to the prospectus.) As the Commission well knows, valuation of a security is a subject on which objective evidence can be marshalled and experts can explain the basis for their conclusions, although other experts may draw different conclusions from the same data. Considering the significance of the pricing determination, some relaxation of the historical ban on soft information would be appropriate, making disclosures permissive in this area. Investors should be able to recognize that the data being offered in jusification of the offering price is inherently self-serving, and they should be able to evaluate such data accordingly.

A major purpose of banning soft information is to keep ultimate value judgments out of a filing. However, this rationale is largely inapplicable in the context of pricing. The prospectus must, of necessity, reflect the ultimate conclusion on value reached by the parties involved -that is, their determination of the public offering price.

In view of these factors, a company willing to explain the basis of the pricing negotiations should be permitted (but for the time being not required ${ }^{110}$ ) to do so, within limits, so that investors can make an independent analysis of the factors considered. The present approach forces investors to accept the offering price on a take-it-or-leave-it basis, without benefit of the analysis of the parties most involved. Public investors do not see this type of information which is often circulated privately among syndicate members. It is reasonable to allow disclosures on pricing to be optional and not mandatory. If an issuer wishes to bolster the credibility of its pricing by explaining how the price was determined, it should be free to do so. Investors can then analyze such data. On the other hand, when an issuer elects not to inform the public meaningfully about the method of pricing, investors will be free to draw whatever inferences seem appropriate from the fact that no supporting data are offered.

Any policy changes in this area should be taken in small steps and on an experimental basis. A body of experience should be accumulated

110 In view of considerations discussed above, it would probably be unfair to force all issuers to make disclosures of this type. In any event, even if disclosures were mandatory, companies reluctant to discuss specifics would probably retreat to relatively meaningless generalizations mentioning all of the obvious factors, which would merely clutter prospectuses without significantly assisting investors. 
at each level, before proceeding to the next level of disclosure. Possibly a standard format could involve a check list of items which must be analyzed (if applicable) when information on pricing is to be included in a prospectus. Ultimately, if experience is favorable, the standardized disclosures of this type may be made mandatory.

Perhaps permissive disclosures of this type should stop short of specific dollar earnings projections, to avoid a false appearance of certainty. But even without firm numbers regarding future expectations, disclosures could be tailored to indicate the factors considered, the relative weighting given to each, and similar matters. Hard data, such as documented, historical industry trends, reported price-earnings ratios of comparable companies, the issuer's prior growth rate, and its return on capital, that were part of the price calculation should be included.

Underwriters typically prepare elaborate charts containing relevant information about the issuer and comparable companies, including data on sales, price-earnings ratios, net worth, working capital ratios, return on investment, and other analyses. There are detailed discussions between issuer and underwriter concerning the relevance of various comparisons-for example, the fact that one company deserves a particularly high price-earnings ratio because of its growth rate, while another has a particularly low ratio because of a high ratio of debt to equity. There should be no objection in principle to the inclusion, at the issuer's election, of such a comparison chart in a prospectus, with relevant comments about other public companies. Of course, the data selected for tabulation should be balanced. The issuer should not be permitted to select only companies or only items of information that will show a favorable comparison. The issuer should not, however, be required to warant the accuracy of the information about comparable companies appearing on the chart. The issuer should warrant only that the tabulated information reflects data available from public sources and is reasonably believed to be true. Further guidelines for the presentation of such information could be evolved as experience accumulates.

\section{Market and Conopetitive Conditions}

Critics of disclosure policy have called for further information in SEC filings dealing with the market position of the issuer and other competitive factors. The traditional boilerplate disclosures which customarily appear in prospectuses have been characterized as "worse than worthless" by Chairman Casey. ${ }^{111}$ The Commission's hot issue

111 Address by SEC Chairman Casey, New York Law Journal and the Association of the Bar of the City of New York, Apr. 21, 1972, at 8. 
proposals made certain specific recommendations to improve disclosure in this regard..$^{112}$ No doubt there are aspects of market position and competition where improvements in disclosure are clearly called for; for example, many companies could do a better job of identifying the industries in which they compete as well as the specific sources of their competition. But while better disclosure is advisable, there are several factors that counsel against making disclosure about competition mandatory. Competition is somewhat unique among the disclosure topics in that it deals primarily with information not relating directly to the issuer. A company may have relatively little or no information available about the current and prospective position of its competitors or the market place as a whole. The information that is available may be so incomplete or difficult to verify that it would be unfair to adopt mandatory disclosure requirements under threat of liability for inaccuracies.

Furthermore, a particular management may have no special qualifications, as compared with market analysts or economists generally, to make industrywide evaluations. Companies may be affected by trends or developments which their own managements have no expertise in predicting. ${ }^{113}$ In many instances, the sources of information are as available to investors as they are to the issuer; a particular company may have no special access to data about its industry. ${ }^{114}$ Without articulating any of these policy bases for its decision, at least one court has indicated that a prospectus need not discuss industrywide trends. ${ }^{115}$

If mandatory disclosure is extended to evaluations of the issuer's

112 E.g., SEC Securities Act Release No. 5276, at 5-6 (July 26, 1972) (proposed amendments to Form S-1, Item 9 (a) (1) and Instruction 1 thereto); SEC Securities Act Release No, 5279, at 5 (July 26, 1972) (proposed amendment to Guide 5).

113 For example, the market for grass seed is vitally affected by the rate of new housing construction. Wong, When Housing Booms, So Do Grass Seed, Art, Toilets, Rugs and Frit, Wall St. J., May 25, 1972, at 1, col. 6. There is no reason to believe that companies in the grass seed business have an expertise superior to others in the financial community for prognosticating housing starts.

114 The author knows of at least one instance where an investment banking firm obtained important information about an issuer's competitors which was unavailable to the issuer itself.

115 Finally, the claim that the prospectus should have predicted the saturation of the bowling market is unsupported in fact or law. Plaintiff has not offered evidence to support the saturation argument, and moreover, even if such saturation had been proved, such hindsight predictions do not belong in prospectuses and might even result in liability for violation of S.E.C. regulations. Under no construction of the securities laws "is an insider obligated to confer upon outside investors the benefit of his superior financial or other expert analysis by disclosing his educated guess or predictions." SEC v. Texas Gulf Sulphur, [401 F.2d 833,I 848 .

Colonial Realty Corp. v. Brunswick Corp., 337 F. Supp. 546, 552-53 (S.D.N.Y. 1971). Interestingly, the case of Escott v. BarChris Constr. Corp., 283 F. Supp. 643 (S.D.N.Y. 1968), also involved the bowling industry. While numerous specific deficiencies were found in the BarChris prospectus, many of which were failures to disclose adverse consequences resulting from industry oversaturation, the prospectus was not alleged or found to be deficient for failing to disclose, as such, this fundamental industrywide trend. 
market, there may be pressure to include market studies in filings. Of course, almost every company can produce some type of analysis of its markets and its competitive position, even if it is only the "feel" of its executives for the industry. Indeed, the intuition of an executive experienced in the industry may be a much more reliable basis for an investment decision than an elaborate survey by an outside consultant. But if there is a mandatory disclosure for market studies "if available,"116 issuers may be faced with a troublesome dilemma. Since almost any issuer will have some data available, to disclaim the existence of a study may expose the issuer to the charge of making a misstatement. Alternatively, the issuer may feel that the data available is not sufficiently authoritative to include in its prospectus-indeed, it may be aware of very formal studies which reach conclusions the issuer considers completely erroneous. Furthermore inclusion of a study in a prospectus may carry with it the implied representation that the study was reasonable in scope and methodology. This creates a practical problem, however, since it may be difficult (or impossible), in the context of a disclosure filing, to describe adequately the scope and limitations of a market survey, which may range from a superficial examination to an expensive, in depth analysis. If a disclosure document describes a study which later events show reached an overly optimistic conclusion, the company may be hard pressed to explain why the study was not more comprehensive. Experience teaches us that even the best market surveys are not necessarily reliable. ${ }^{117}$

In the last analysis, the responsibility for verifying the markets and competitive position of an issuer should rest very heavily with the broker-dealers distributing or recommending the issuer's securities.

116 SEC Securities Act Release No. 5276, at 6 (July 26, 1972), proposed the following new instruction to the Form S-1, Item 9, Description of Business:

Instructions. 1. If the registrant proposes to, or has recently entered or introduced a new line of business or product requiring the investment of a material amount of the registrant's resources, indicate whether there have been market studies performed, briefly describe such studies and furnish supplementally any report prepared in connection therewith. The present status of product development should also be disclosed (e.g., whether in planning stage or whether further development is necessary).

George F. Doriot, President of American Research and Development Corp., and one of the country's leading venture capitalists, has testified that new companies should be required to do market research before making a public offering, and should be required to state in the prospectus whether or not this has been done. CCH FED. SEC. L. REP., Report No. 414, at 6 (Mar. 8, 1972) (testimony before SEC's hot-issue hearing).

117 Witness these disasters suffered by well managed giant companies which miscalculated the potential for profitable markets: RCA's $1971 \$ 500$ million write-off of its general purpose computer line, after losing hundreds of millions of dollars; General Foods' $\$ 93$ million Burger Chef write-off; and the disasters in the automobile industry with Ford's Edsel and the Kaiser-Fraiser automobiles. See Singing Those Write-Off Blues, FORBES, Mar. 15, 1972, at 26.

The SEC's recent proposals for expanded proposals about large write-offs would require a great deal of predictive or soft information in filings. See SEC Securities Act Release No. 5313 (Oct. 2, 1972). 
A broker-dealer engaged in these activities makes the implied representation that it has adequately investigated the company and has made a professional judgment concerning the securities offered. ${ }^{118}$ The basis of this economic judgment may be far too complex or subjective to require a specific analysis in a disclosure document. As in the case of management evaluations, ${ }^{119}$ there may be inherent limitations in the extent to which a disclosure filing can or should attempt to educate the public regarding competitive and market factors.

\section{Problems of Liability}

A principal objection to soft disclosures in SEC filings is the inherent risk of liability if soft information is challenged, an objection which should not be underestimated. The potential liability for an inadequate disclosure document can be enormous. As a matter of proof, it may be much more difficult to determine the adequacy of a soft disclosure, as contrasted with a hard one. (Of course, this factor may work in favor of the party preparing the disclosure document, since the burden of proof would normally rest with the party challenging its adequacy.)

Yet, problems of liability should not be overestimated. Those involved with the public securities markets have become accustomed to dealing with soft information, and they have learned to do so notwithstanding the ever present risk of liability. Company managements disseminate large amounts of soft information through press releases, communications with analysts, and reports to shareholders. False or misleading disclosures through any of these non-filed channels of communication can expose issuers and their principals to serious liabilities. The standards for determining the adequacy of a disclosure, as well as the consequences for inadequate disclosure, do not vary significantly depending on whether or not the communication is an SEC filing. Yet, company managements have adapted to making disclosures subject to these potential liabilities and, by and large, have done a highly responsible job in communicating soft information to the public.

Likewise, broker-dealers have learned to deal with soft information despite the risks. Most investment recommendations carry with them some express or implied soft representation-for example, concerning the future expectations for the company or the market price of its securi-

118 Escott v, BarChris Constr. Corp., 283 F. Supp. 643, 696-97 (S.D.N.Y. 1968); Richmond Corp., SEC Securities Act Release No. 4584 (Feb. 27, 1963), in [1961-1964 Transfer Binder] CCH FED. SEC. L. REP. II 76,904; Charles E. Bailey \& Co., 35 S.E.C. 33 (1953). See SEC Securities Act Release No. 5275 (July 26, 1972).

119 See text accompanying note 86 supra. 
ties. Broker-dealers know that if their recommendations are not reasonably based they will be exposed to serious consequences. However, the risk in dealing with soft information has certainly not deterred the process of giving investment recommendations.

Withholding of information can also mislead and deceive the investing public. If important soft information is available, public policy favors making the best disclosure that can be made in good faith under the circumstances, rather than total non-disclosure. This approach was followed in Feit v. Leasco Data Processing Equipment Corp. ${ }^{120}$ That case involved an exchange offer registration statement, where the issuer sought to acquire control of an insurance company which had substantial "surplus surplus"-that is, excess funds which could be withdrawn from the insurance company without impairing legally required reserves. The amount of surplus surplus concededly was difficult to compute, with estimates ranging from $\$ 80$ million to $\$ 125$ million. The issuer's future plan to withdraw these funds, as well as the amount of funds available, both represented soft information. The court held that the plan to withdraw surplus surplus was an essential part of the economic reality of the transaction. Thus, even though the issuer's future plans were somewhat uncertain, and the dollar amount of excess funds was hard to estimate, the prospectus was deemed deficient for failing to make a good faith effort to disclose the issuer's plans and the existence of the surplus funds. ${ }^{121}$

Public ownership imposes a heavy responsibility on management to keep public investors adequately informed. There may be occasions when this responsibility requires hard decisions on how disclosure should be made-decisions which others can second-guess with the benefits of hindsight. But the mere fact that the decisions are difficult does not justify the withholding of important information from the public. Rather, management should be required to make the best disclosure which can be made under the circumstances. ${ }^{122}$ Many aspects of man-

120332 F. Supp. 544 (E.D.N.Y. 1971).

121 Although it was the omission of a relatively objective fact (the existence of the surplus surplus) which was the most important failure of the issuer, the filing was also deficient in not estimating the admittedly uncertain amount of the surplus. Moreover, while the court did not require disclosure of "preliminary contingency planning," id. at 568 , it chided the issuer for not apprising the insurance company's shareholders of its intention "to remove [the surplus] 'as soon as practicable," id. at 565.

122 In a release captioned "Notice to Registrants Engaged in Defense and Other Long Term Contracts and Programs of the Need for Prompt and Accurate Disclosure of Material Information Concerning Such Activities," SEC Securities Act Release No. 5263 (June 22, 1972), in CCH FED. SEC. L. REP. \ 78,852, the Commission stated:

[C] osts to be incurred in the performance of [government] contracts and ultimate profit to be realized often cannot be known in the early stages of the contract. Accordingly, such matters are necessarily the subject of estimates which are difficult to make with any certainty. Notwithstanding such difficulties, registrants have an obligation to make every effort to assure that progress on material 
agerial responsibility are fraught with potential risk, but these risks cannot be completely eliminated without prejudicing legitimate interests of public investors. Chairman Casey has expressed the point well:

There is little worthwhile in business-or elsewherethat does not involve at least some risk; but the ultimate defense is the exercise of sound judgment, not the abdication of responsibility. ${ }^{123}$

Of course, it is essential to use a sensible standard in judging the adequacy of a soft disclosure. As has been recognized, ${ }^{124}$ a person making a soft disclosure in good faith and with reasonable prudence should be protected against liability, even if his opinion or prediction turns out to be incorrect.

Proposals have been made for a rule to exclude designated items of soft information in a prospectus from potential liabilities under section 11 of the 1933 Act. There is precedent for exempting a filed document from liabilities attaching to inadequate "filings." may be useful to reduce the potential section 11 liability of underwriters, directors, controlling persons, and experts. Presumably, potential liability would remain under the anti-fraud rules, and the public would thereby be adequately protected.

\section{Conclusion}

Soft information may be highly relevant to investment decisions. It is widely used in the financial community. Although the policy reasons for barring it from filings have been, and still are, valid considerations, there are strong countervailing considerations which must be balanced, particularly the objective of giving investors the maximum amount of useful information. The prevailing practice has resulted in filings which convey an artificial or distorted view of economic realities and withhold a great deal of useful and available information from investors.

The time has come for a reappraisal. Within controlled limits, and

contracts-such as earnings, losses, anticipated losses or material cost overrunsis properly reflected in the registrant's financial statements and, where necessary to a full understanding, discussed in appropriate textual disclosure.

Id. at 81,865 (emphasis added).

123 Address by SEC Chairman Casey, National Industrial Conference Board, Nov. 18,1971 , at 16.

124 Dolgow v. Anderson, 53 F.R.D. 664 (E.D.N.Y. 1971), affd per curiam, 464 F.2d 437 (2d Cir. 1972).

1251934 Act Rule 13a-13(d), 17 C.F.R. \& 240.13a-13(d) (1972) (relating to Form 10-Q). An earlier SEC proposal would have treated only a portion of the Form 10-Q report as being a "filed" document for purposes of the $\$ 18$ liability provision. SEC Securities Exchange Act Release No. 8683 (Sept. 15, 1969). 
on an experimental basis, we should evolve new standards that would permit, and in some instances require, broader use of soft information in filings if it is relevant, material, reasonably reliable, and adequately qualified. There may be a risk that some investors will misuse soft information or be misled by it. There may be increased risk of liability against companies and their managements who will face difficult problems in dealing with soft information. But these risks are acceptable ones, in view of the corresponding benefits to be realized by giving more useful information to investors.

A change in prevailing policy seems inevitable. The preceding pages have explored some of the basic implications that must be considered, though no attempt has been made to develop a comprehensive set of specific answers. The objective of this Article has been realized if it helps articulate the relevant questions and place them in proper perspective. 